\title{
Pseudomyona from the Cambrian of North Greenland (Laurentia) and the early evolution of bivalved molluscs
}

John S. Peel

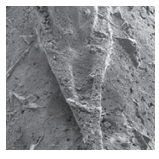

The laterally compressed, univalve, Cambrian (Miaolingian Series, Drumian Stage) mollusc Pseudomyona is recorded for the first time from Laurentia. Distinctive internal moulds of the type species Pseudomyona queenslandica, a species otherwise known from Australia and northern Siberia, are described from the Ekspedition Bræ Formation of southern Lauge Koch Land, North Greenland. A new species, Pseudomyona groenlandica, characterised by a proliferation of hinge teeth on the supra-apical surface, is described from the overlying Fimbuldal Formation of south-east Freuchen Land. The increase in hinge teeth supports the hypothesis that the bivalved Tuarangia from the Miaolingian Series (Guzhangian Stage) of New Zealand and Bornholm, Denmark, evolved from Pseudomyona. Although bivalved, Tuarangia is not interpreted as Class Bivalvia, but as the most derived member of an early clade in the evolution of Class Rostroconchia. The emended Order Tuarangiida, containing Tuarangia and Pseudomyona, forms a sister group to ribeirioids and later rostroconchs $\bullet$ Key words: Mollusca, Rostroconchia, Bivalvia, Cambrian (Miaolingian), Greenland, Laurentia.

Peel, J.S. 2021. Pseudomyona from the Cambrian of North Greenland (Laurentia) and the early evolution of bivalved molluscs. Bulletin of Geosciences 96(2), 195-215 (10 figures). Czech Geological Survey, Prague. ISSN 1214-1119. Manuscript received February 27, 2021; accepted in revised form March 16, 2021; published online April 4, 2021; issued April 11, 2021.

John S. Peel, Department of Earth Sciences (Palaeobiology), Uppsala University, Uppsala, Sweden; john.peel@ pal.uu.se

There is broad agreement from genomic and morphological studies of present day bivalves that the Ordovician-Recent members of the Class Bivalvia Linnaeus, 1758 form a monophyletic group, although some relationships within the group remain unresolved (Schneider 2001; Giribet 2008; Plazzi et al. 2011; Sharma et al. 2012, 2013; Bieler et al. 2014; González et al. 2015; Lemer et al. 2019). However, the derivation of Bivalvia from ancestral univalved molluscs and its stem group evolution in the Cambrian remains the subject of speculation (Cope 1997, 2000; Carter et al. 2000, 2011; Fang \& Sánchez 2012; Cope \& Kř́ž 2013; Ponder et al. 2020). Two Cambrian bivalved groups are recognised as potential ancestors of Bivalvia but their morphological dissimilarity, together with the general absence of material from the late Cambrian (Furongian), obscures the evolutionary pathway. The Order Fordillida Pojeta, 1975 includes Fordilla Barrande, 1881 (Fig. 1L, N) and Pojetaia Jell, 1980 (Fig. 1M) and its oldest members appeared in the Terreneuvian. The Order Tuarangiida MacKinnon, 1982 contains Tuarangia MacKinnon, 1982 (Fig. 1K) and is described from the late Miaolingian Series (Guzhangian Stage), about $20 \mathrm{Ma}$ later. Tuarangia and the youngest specimens of Pojetaia occur together in the Guzhangian of Denmark (Hinz-Schallreuter 2000).

Carter et al. (2011) rationalised the dilemma concerning origin(s) by recognising two major divisions of Class Bivalvia. A Grade Euprotobranchia Nevesskaja, 2009 embraced the two orders Fordillida and Tuarangiida, which were considered in some way likely to be ancestral to crown group bivalves, but together did not comprise a monophyletic entity. The grade recognises the dichotomy as stem group bivalves between Fordilla and Pojetaia, and Pseudomyona Runnegar 1983 and Tuarangia, discussed by Runnegar \& Pojeta (1992), as a result of which Pseudomyona and Tuarangia were not considered to be Bivalvia. Carter et al. (2006) had considered Tuarangia, Pseudomyona, Watsonella Grabau, 1900 (Fig. 1J) and Anabarella Vostokova, 1962 to form a sister group to Pojetaia and Fordilla and post-Cambrian Bivalvia.

A Clade Eubivalvia Carter in Carter et al. (2011) included the post-Cambrian groups traditionally regarded as Bivalvia, but Sharma et al. (2013), Bieler et al. (2014) and others considered Fordilla to be a crown group bivalve. Conversely, Ponder et al. (2020, p. 552) placed 
just Tuarangiida within Eubivalvia, citing Carter et al. (2000), and left Fordillida within Euprotobranchia.

Numerous claims of Cambrian bivalves have been evaluated by Runnegar \& Pojeta (1992), Pojeta (2000), Geyer \& Streng (1998) and Elicki \& Gürsu (2009) but just three well known genera (Fordilla, Fig. 1L, N; Pojetaia, Fig. 1M; Tuarangia, Fig. 1K) and two less well known taxa (Camya Hinz-Schallreuter, 1995; Anhouriella Geyer \& Streng, 1998) have been maintained. However, it should be recalled that members of the Class Stenothecoida Yochelson, 1969 are possibly the most common bivalves in the Cambrian in which the two valves, as in Bivalvia, are disposed around a plane of symmetry lying between the valves. In Greenland, stenothecoid shells range from Cambrian Series 2 to Miaolingian Series, Guzhangian Stage (Peel 1988). While interpreted as molluscs by Yochelson (1969), or as brachiopods or molluscs by subsequent workers, the internal structures of stenothecoids (Koneva 1976, 1979) show no similarity to other members of the Mollusca, and the relationships of the group are obscure (Ponder et al. 2020).

A number of univalved molluses referred to the Class Rostroconchia Pojeta et al., 1972 and the Class Helcionelloida Peel, 1991a resemble bivalves in developing laterally compressed shells adapted to a semi-infaunal mode of life (Fig. 1H-J). Gubanov et al. (1999) and Gubanov \& Peel (2003) considered this adaptation in helcionelloids to be the first major adaptive strategy in Cambrian molluscs, although many specimens lie within a size range $(<1000 \mu \mathrm{m})$ typical of present day meiofauna (Higgins \& Thiel 1988). Watsonella has a lateral profile similar to Fordilla, although the specimen illustrated herein (Fig. 1J; Cambrian, Terreneuvian Series, basal Stage 2) has a straighter dorsum in lateral perspective than most specimens illustrated by Devaere et al. (2013) or Guo et al. (2021). Watsonella and the strongly coiled, laterally compressed Anabarella are widely regarded as ancestral to Fordilla, not least on account of the longitudinal ridge complex along the dorsum of the supra-apical surface and convex ventral margin (Kouchinsky 1999; Devaere et al. 2013, fig. 14) suggestive of an incipient hinge zone. Runnegar \& Pojeta (1992) and Vendrasco et al. (2011a) noted that similarity in shell microstructure between Watsonella and Fordilla supports this evolutionary relationship. Pojetaia (Fig. 1M) has a small number of well-developed hinge teeth, usually absent in Fordilla, and an opisthodetic ligament, but it is placed within the same Family Fordillidae (Ponder et al. 2020). Pojetaia is widely distributed in Terreneuvian-Miaolingian strata (Elicki \& Gürsu 2009, Hinz-Schallreuter 2000).

Although bivalved, Tuarangia, from the late Miaolingian (Guzhangian Stage) of New Zealand and Denmark (MacKinnon 1982, 1985; Berg-Madsen 1987; Hinz-Schallreuter 1995, 2000) is morphologically quite distinct from the fordillids, with numerous hinge teeth distributed on either side of the median, amphidetic, ligament in lateral view (Fig. 1K), and a different shell microstructure (Runnegar \& Pojeta 1992; Vendrasco et al. 2011a, b). Runnegar \& Pojeta (1992) concluded that Tuarangia did not share a common bivalved ancestry with Fordilla and Pojetaia but formed a separate clade together with Pseudomyona (Fig. 1A). Pseudomyona, however, is clearly univalved in contrast to the bivalved Tuarangia, which prompted Hinz-Schallreuter (2000) to accept Tuarangia as a member of Class Bivalvia, recalling the opinions of MacKinnon $(1982,1985)$ and BergMadsen (1987), but to exclude Pseudomyona. Runnegar \& Pojeta (1992) noted that Class Bivalvia would not be monophyletic if Tuarangia, Fordilla and Pojetaia were all interpreted as true bivalves, and concluded that Tuarangia was not a true bivalve, an opinion endorsed by Vendrasco (2012). The assignment of Tuarangiida to Eubivalvia by Ponder et al. (2020, p. 552) and placement of fordillids away from the crown group of Bivalvia is a decision that echoes the widely denigrated opinion of Yochelson (1981) concerning Fordilla, but is contrary to the crown group status of fordillids interpreted by Sharma et al. (2013), Bieler et al. (2014) and others.

The present paper explores the relationship between Pseudomyona and Tuarangia in describing internal moulds of two species of Pseudomyona from the Miaolingian Series (Drumian Stage) of North Greenland. Together, these species represent the first record of the genus from Laurentia. Pseudomyona groenlandica sp. nov. is characterised by the proliferation of hinge teeth along the dorsal margin when compared to the type species Pseudomyona queenslandica (Runnegar \& Jell, 1976), which was first described from the Drumian of Australia (Runnegar \& Jell 1976). This evolution in hinge structure confirms the relationship between Pseudomyona and Tuarangia, and supports their interpretation as members of a clade within Rostroconchia.

\section{Materials and methods}

Specimens of Pseudomyona from Greenland are derived from Cambrian (Miaolingian Series) carbonates within a belt of Lower Palaeozoic strata that crops out across North Greenland as part of the southern shelf succession of the transarctic Franklinian Basin (Higgins et al. 1991a, b). Cambrian stratigraphy in the Freuchen Land to Peary Land region was described by Ineson et al. (1994) and Ineson \& Peel (1997, 2011; Fig. 2B). The described specimens are preserved as internal moulds, which are compared with silica replicas of entire shells from the Kuonamka Formation (Miaolingian Series) of northern Siberia (Gubanov et al. 2004). 


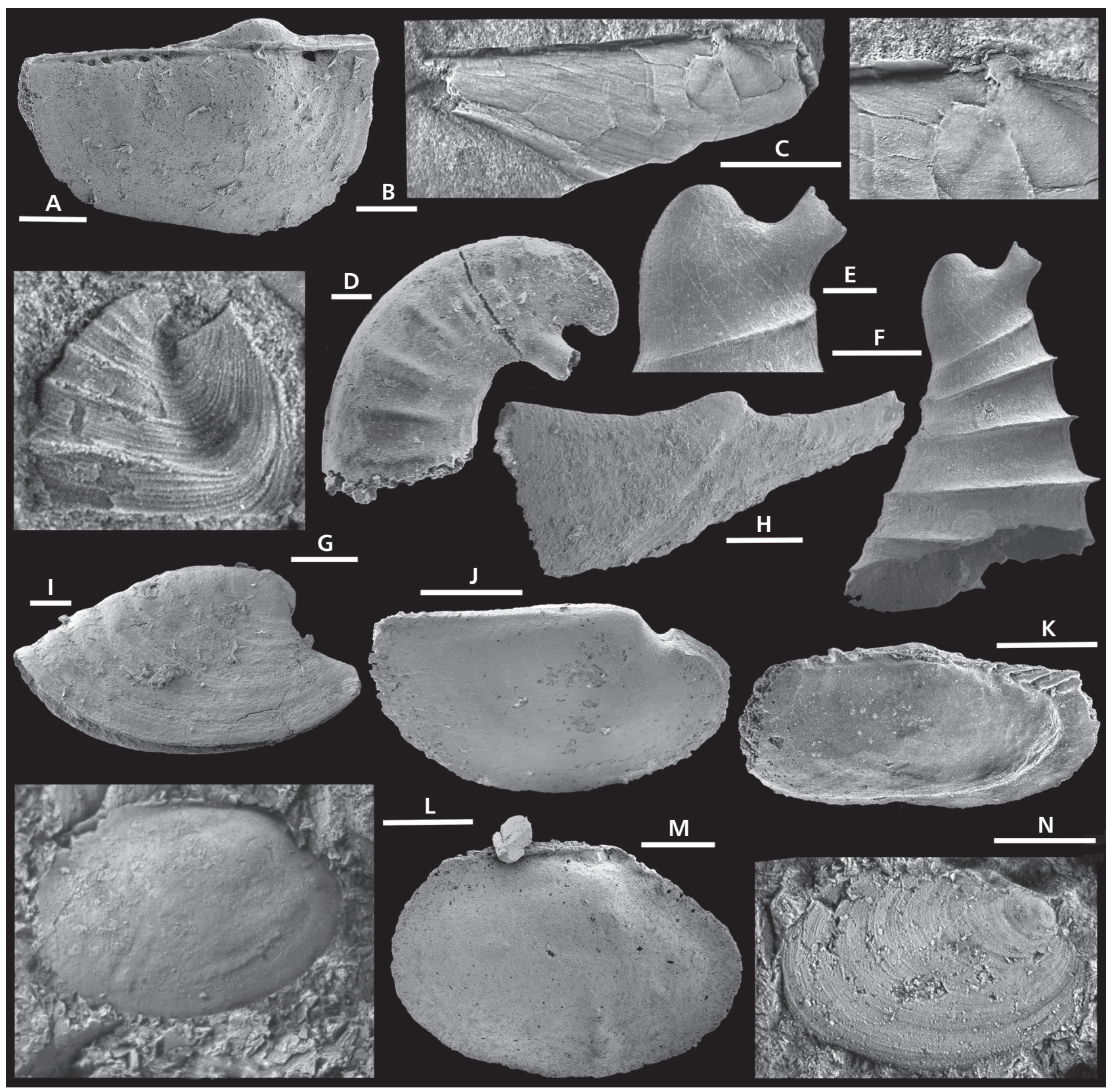

Figure 1. Cambrian and Ordovician molluscs. All specimens oriented with sub-apical surface to the right. • A - Pseudomyona groenlandica sp. nov., Fimbuldal Formation, Miaolingian, Drumian Stage, lateral view of internal mould, PMU 377511 from GGU sample 315006, Freuchen Land, North Greenland. • B, C - Pinnocaris lapworthi Etheridge, 1878, Ordovician, Girvan, southern Scotland, lateral view of partially crushed specimen showing the coiled early growth stage (C), NHM In 20400. D - Runnegarella americana (Runnegar \& Pojeta, 1980), Forteau Formation, Cambrian Series 2, Stage 4, western Newfoundland, lateral view of internal mould, PMU 25031. E , F - Yochelcionella ostentata Runnegar \& Jell, 1976, Kuonamka Formation, Cambrian Series 2, Stage 4, northern Siberia, lateral views of silica replica, SMNH 160579, with detail of apex (E) showing radial ornamentation (images Alexander Gubanov). $\bullet \mathrm{G}$ - Eotebenna arctica Peel, 1989, Henson Gletscher Formation, Cambrian Series 2, Stage 4, south-west Freuchen Land, North Greenland, lateral view, MGUH 18.701 from GGU sample 315109, mirrored illustration. $\bullet$ H - Eotebenna viviannae Peel, 1991b, Kuonamka Formation, Cambrian Series 2, Stage 4, northern Siberia, lateral view of silica replica, SMNH Mo 160588 (image Alexander Gubanov). • I - Mellopegma sp., Fimbuldal Formation, Miaolingian, Drumian Stage, southern Lauge Koch Land, lateral view (mirrored), PMU 37506 from GGU sample 315006. - J - Watsonella crosbyi Grabau, 1900, Cambrian, Terreneuvian Series, Heraultia Limestone, Montagne Noire, France, lateral view (mirrored) of internal mould (USTL 1226/10; image Léa Devaere). $•$ K - Tuarangia gravgaerdensis Berg-Madsen, 1987, Andrarum Limestone, Miaolingian, Bornholm, Denmark, dorso-lateral view (mirrored) of internal mould (MGUH 17.451; image Vivianne Berg-Madsen). $\bullet$ L, N Fordilla troyensis Barrande, 1881, Aftenstjernesø Formation, Cambrian Series 2, Stage 4, southern Peary Land, lateral views of internal mould with muscle scar traces (L - MGUH 33533) and external surface showing comarginal ornamentation (N - MGUH 33534). $-\mathrm{M}-$ Pojetaia runnegari Jell, 1980, Aftenstjernesø Formation, Cambrian Series 2, Stage 4, northern Lauge Koch Land, internal mould in lateral view (M - PMU 36935 from GGU sample 315045). Scale bars: $100 \mu \mathrm{m}$ (A, I); $200 \mu \mathrm{m}$ (D, E, H, I, K, M); $500 \mu \mathrm{m}$ (F, J); 1 mm (G, L, N); 3 mm (B, C). 
A

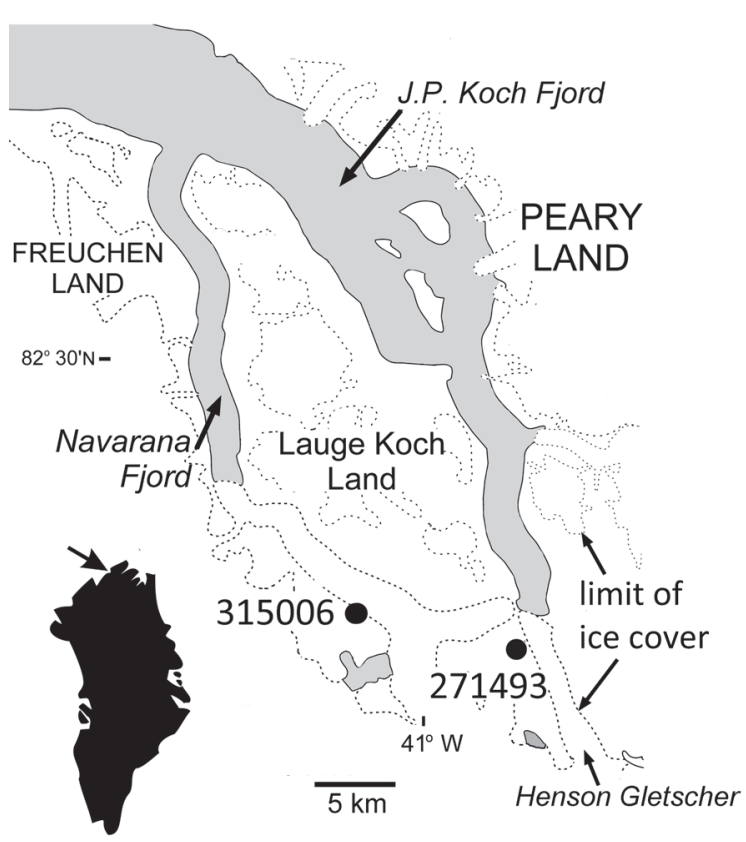

B South Lauge Koch Land North Lauge Koch Land

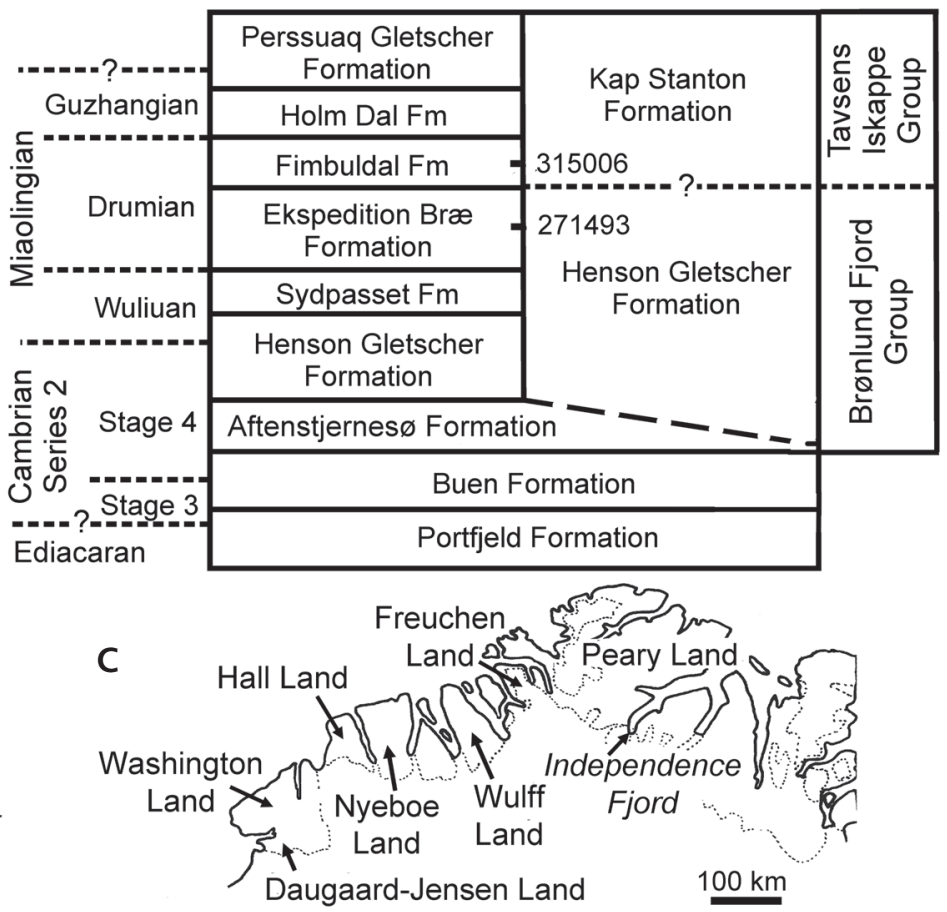

Figure 2. Occurrence of Pseudomyona in North Greenland. • A - GGU sample sites in south-east Freuchen Land and southern Lauge Koch Land, with inset map of Greenland locating J.P. Koch Fjord (arrow). $\bullet$ B - stratigraphic nomenclature with location of GGU samples. $\bullet$ C - land areas in North Greenland.

Pseudomyona queenslandica occurs in the Ekspedition Bræ Formation. GGU sample 271493 was collected by J.S. Peel on $26^{\text {th }}$ June 1978 from about $35 \mathrm{~m}$ above the base of the formation in its type section (Ineson \& Peel 1997, fig. 41) in southern Lauge Koch Land $\left(82^{\circ} 10^{\prime} \mathrm{N}\right.$, $40^{\circ} 24^{\prime}$ W; Fig. 2A); Miaolingian Series, Drumian Stage, Ptychagnostus atavus Biozone (Robison 1984). Trilobites from the Ekspedition Bræ Formation were described by Geyer \& Peel (2017, 2020).

Pseudomyona groenlandica sp. nov. is described from the Fimbuldal Formation, with GGU sample 315006 collected by J.S. Peel on $2^{\text {nd }}$ July 1984 from the recessive interval in the middle of the Fimbuldal Formation on the south-west side of the glacier draining into Navarana Fjord, eastern Freuchen Land $\left(82^{\circ} 17^{\prime} \mathrm{N}, 41^{\circ} 22^{\prime} \mathrm{W}\right.$; Fig. 2A); Miaolingian Series, Drumian Stage, Ptychagnostus punctuosus Biozone (Robison 1984).

The limestone samples were dissolved in $10 \%$ acetic acid to release phosphatic microfossils. Selected specimens were coated with gold prior to stereoscan microscopy, and images were assembled subsequently in Adobe Photoshop CS4.

Terminology is illustrated in Figure 3, in which the straight hinge zone is interpreted as dorsal and the curved margin as ventral. The term half-pegma is introduced for one of a pair of prominent opposing teeth located one on each sub-apical lateral surface, at the dorsum. Unlike a full pegma, which extends from one lateral area to the other across the median plane (Pojeta \& Runnegar 1976), opposing half-pegmas seemingly only come into contact with each other when the ventral margin of the univalved shell is closed.

Institutional abbreviations. - ANU - Australian National University, Canberra; GGU - Grønlands Geologiske Undersøgelse, the Geological Survey of Greenland, now part of the Geological Survey of Denmark and Greenland (GEUS), Copenhagen; MGUH - Natural History Museum of Denmark, Copenhagen; NHM, Natural History Museum, London; PMU - Palaeontological type collection of the Museum of Evolution, Uppsala University; SMNH - Swedish Museum of Natural History, Stockhom; USTL - Université des Sciences et Technologies de Lille, France.

\section{Systematic Palaeontology}

This published work and the nomenclatural acts it contains have been registered in ZooBank http://zoobank.org/ References/9C8A9CE3-E5B1-4283-B522-93047E2CD DF5 
Phylum Mollusca Linnaeus, 1758

Class Rostroconchia Pojeta, Runnegar, Morris \& Newell, 1972

Discussion. - Watsonella (Cambrian, Terreneuvian Series) was considered to be the oldest rostroconch by Pojeta \& Runnegar (1976) on the basis of the interpreted presence of a pegma on the sub-apical surface, but restudy by MacKinnon (1985), Li et al. (2011), Devaere et al. (2013), Kouchinsky et al. (2017) and Guo et al. (2021) has rejected this interpretation. The status of several Miaolingian taxa as possible rostroconchs was discussed by Wagner (1997), Vendrasco et al. (2010; 2011a, b) and Vendrasco (2012). Herein, Order Tuarangiida is considered to form the oldest group of rostroconchs, with Pseudomyona appearing in the early Drumian. Additionally, Rostroconchia includes the orders Ribeirioida Kobayashi, 1933, Conocardioida Neumayr, 1891 and Anetshelloida Mazaev, 2012, although the relationships between ribeirioids, conocardioids and their descendent scaphopods have been questioned (Engeser \& Riedel 1996; Peel 2004, 2006; Mazaev 2012; Vendrasco 2012)

\section{Order Tuarangiida MacKinnon, 1982}

Diagnosis (emended). - Pseudo-bivalved (univalve) or bivalved laterally compressed D-shaped shells with a long straight dorsal hinge zone and convex ventral margin. Hinge zone in pseudo-bivalved forms is flexible with a prominent, raised, undivided early growth stage along the median plane of symmetry and a variable numbers of hinge teeth. Bivalved forms are equivalve, with taxodont dentition consisting of a number of oblique, subparallel, bar-like teeth forming two elements on each valve that are separated by a narrow, erect, amphidetic ligament. Inner shell surface formed of foliated calcite.

Discussion. - MacKinnon (1982) proposed the Order Tuarangiida to contain the single species Tuarangia paparua MacKinnon, 1982 from the Miaolingian of New Zealand, interpreted as a pteriomorph(?) bivalve; he later acknowledged that it might be phylogenetically related to Pseudomyona (MacKinnon 1985). The univalved Pseudomyona was placed together with Tuarangia within the Family Tuarangiidae MacKinnon, 1982, and regarded as a 'quasirostroconch' or bivalved monoplacophoran by Runnegar (1983, p. 133). Hinz-Schallreuter (2000) established the Order Pseudomyonida and Family Pseudomyonidae for Pseudomyona. She stated that there was no indication of the pegma characteristic of rostroconchs in the pseudo-bivalved shell of Pseudomyona, an observation contradicted herein. Parkhaev (2019) placed Pseudomyona as Bivalvia, family incertae sedis.
In contrast to Order Pseudomyonida, there is wide usage of Order Tuarangiida in the literature on account of its relevance to discussions concerning the origin of Bivalvia (MacKinnon 1982, 1985; Berg-Madsen 1987; Carter et al. 2000, 2011; Elicki \& Gürsu 2009; Fang \& Sánchez 2012; Ponder et al. 2020). For this reason, and its historical priority, Order Tuarangiida is retained here, although with significant emendation from the concept of the original author (MacKinnon 1982).
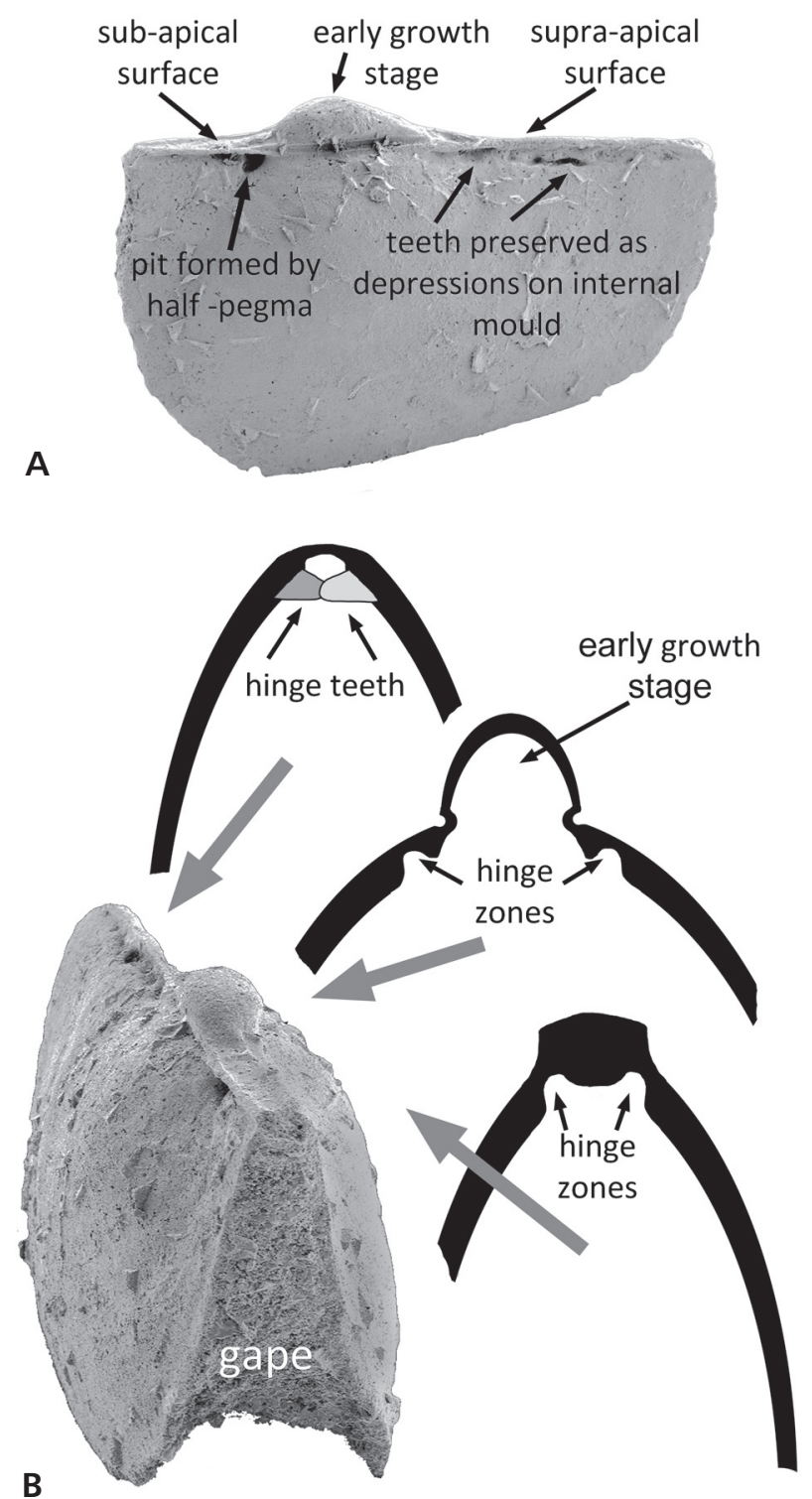

Figure 3. Morphological terminology of Pseudomyona groenlandica sp. nov. - A - internal mould in lateral view showing principal morphological terms. $\cdot$ B - internal mould in oblique dorsal view showing sub-apical surface and gape between lateral surfaces. Schematic cross-sections show relationship between features of the internal mould and shell (black). Ridges on the internal mould correspond to grooves on the shell interior representing hinge zones. 
Family Tuarangiidae MacKinnon, 1982

Diagnosis. - Small elongate, subquadrate to trapezoidal bivalves with long straight hinge line and very subdued umbones near lateral midline. Dentition taxodont consisting of a number of oblique, subparallel bar-like teeth forming two elements on each valve that are separated by a narrow, erect, amphidetic ligament (slightly re-phrased from MacKinnon 1982).

Family Pseudomyonidae Hinz-Schallreuter, 2000

Diagnosis (emended). - Pseudo-bivalved, laterally compressed with prominent early growth stage raised above the straight, flexible, hinge zone; comarginal growth lines continuous across the dorsal line. Few to many hinge teeth developed mainly along the supra-apical surface, with more prominent teeth adjacent to the terminations of the early growth stage interpreted as half-pegmas.

\section{Genus Pseudomyona Runnegar, 1983}

1976 Myona? Runnegar \& Jell, p. 135.

1983 Pseudomyona Runnegar, p. 140.

Type species. - Myona? queenslandica Runnegar \& Jell, 1976 from the Currant Bush Limestone (Gowers Formation), Miaolingian Series, Drumian Stage, Thorntonia, Georgina Basin, Queensland, Australia.

Diagnosis (emended). - Pseudo-bivalved, with comarginal ornamentation continuous across the dorsum; bilaterally symmetrical, with dorsal plane of symmetry separating the lateral surfaces. D-shaped in lateral view with the straight dorsal hinge line interupted by a swollen early growth stage located at about one third of the distance from the sub-apical margin to the supra-apical margin. Inner surface with prominent grooves (ridges on the internal mould) on the dorsal area extending from alongside the early growth stage to each extremity. Teeth on the dorsal margin of each lateral surface forms pits on the internal mould; sub-apically, usually a single deep pit (half-pegma), but supra-apically a single pit or series of up to 10 pits representing interdigitating teeth.

Discussion. - The early growth stage in Pseudomyona forms a distinctive elevation above the general level of the dorsum and is located closer to the sub-apical margin; the supra-apical surface is extended, tapering towards the supra-apical margin (Fig. 3A). The greatest height and width (thickness) are beneath the early growth stage (Figs 1A, 3A). A similar arrangement is seen in the Late Ordovician, pegma-bearing, Pinnocaris lapworthi Etheridge, 1878 where the coiling of the elevated early whorls is clearly visible, and the supra-apical surface is much more extended (Peel 2004; Fig. 1B, C). In contrast, Eotebenna viviannae Peel, 1991b, which occurs together with Pseudomyona queenslandica in Siberia (Gubanov et al. 2004), tapers towards the sub-apical margin and expands towards the supra-apical margin (Fig. 1H). Internal moulds of the latter, however, show none of the features of a dorsal hinge present in Pseudomyona (Peel 1991a, b). Although laterally compressed, Eotebenna arctica Peel, 1989 displays an upright form with a planar aperture (Fig. 1G), unlike the curved lateral ventral margins of Pseudomyona, although the aperture continues into a deep sub-apical sinus. Yochelcionella ostentata Runnegar \& Jell, 1976 and Runnegarella americana (Runnegar \& Pojeta, 1980) develop tall shells with the characteristic snorkel located high above, and separate from, the plane of the aperture (Fig. 1D-F).

The Terreneuvian Watsonella (Fig. 1J) and some specimens of the contemporaneous Anabarella plana (Gubanov \& Peel 2003) have a similar elongate form to Pseudomyona but lack the prominent, protruding early growth stage of the latter. Furthermore, they show no evidence of teeth along the dorsal surface of the internal mould (Fig. 1J). Most specimens of Watsonella have a convex dorsal profile in lateral view, unlike the straight dorsum of Pseudomyona, while typical Anabarella are coiled through almost one whorl (Gubanov \& Peel 2003). Ridges and grooves along the dorsal crest of Watsonella and Anabarella (Li et al. 2011, Devaere et al. 2013, Guo et al. 2021) suggest the presence of a functional dorsal hinge, as in Pseudomyona. Mellopegma (Cambrian Series 2-Mialongian Series) differs from Pseudomyona in its convex supra-apical surface in lateral view, with a slightly overhanging apex (Fig. 1I), whereas the dorsal surface in Pseudomyona is straight, with an upright early growth stage. Mellopegma, and the morphologically similar Eurekapegma MacKinnon, 1985 from the Miaolingian of New Zealand (MacKinnon 1985, Runnegar 1996), lack structures indicating a flexible hinge zone.

Two species of Pseudomyona are recognised and described below, distinguished from each other by the development of a long series of interdigitating hinge teeth along the supra-apical surface in Pseudomyona groenlandica sp. nov.

\section{Pseudomyona queenslandica (Runnegar \& Jell, 1976)}

Figures 4, 5

1976 Myona? queenslandica Runnegar \& Jell; p. 135, fig. 8d, 4-9.

1978 Myona? - Runnegar, pl. 2, figs 26, 27.

1983 Pseudomyona queenslandica. - Runnegar, p. 140, figs 6,7 . 
1992 Pseudomyona queenslandica. - Runnegar \& Pojeta, fig. 3a, c-d, f-g.

1995 Pseudomyona queenslandica. - Hinz-Schallreuter, p. 82, fig.7.1-7.3.

2000 Pseudomyona queenslandica. - Hinz-Schallreuter, p. 239 , fig. $9 \mathrm{~s}$.

2004 Pseudomyona queenslandica. - Gubanov et al., p. 12, fig. 9a-s.

2011 Pseudomyona. - Vendrasco et al., p. 844.

Holotype. - ANU 29071, Currant Bush Limestone (Gowers Formation), Thorntonia, Georgina Basin, Queensland, Australia; Miaolingian Series, Drumian Stage (Floran local stage).

Type horizon and locality. - Currant Bush Limestone (Gowers Formation), Thorntonia, Georgina Basin, Queensland, Australia; Miaolingian Series, Drumian Stage (Floran local stage).

Material. - PMU 37507-37510 from GGU sample 271493, south-east Lauge Koch Land, North Greenland (Fig. 2A), type section of the Ekspedition Bræ Formation. SMNH 160598, 160599, 160600, 160602 and one associated specimen (Fig. 4J), from a total of 27 specimens from locality 8/32, Kuonamka Formation, Bol'shaya Kuonamka River, northern Sibera, section 8 of Gubanov et al. (2004, figs 1, 2) and Kouchinsky et al. (2011, figs 1, 2), Miaolingian Series, Drumian Stage, Tomagnostus fissus-Paradoxides sacheri Zone.

Runnegar \& Jell (1976) described three phosphatised internal moulds from the Currant Bush Limestone (Gowers Formation) of Queensland, Australia (Miaolingian Series, Drumian Stage), with additional specimens described by Runnegar (1983). Hinz-Schallreuter (1995) noted 13 internal moulds also from the Currant Bush Limestone (Gowers Formation) of Thorntonia, Queensland.

Diagnosis (emended). - Type species of Pseudomyona in which each lateral surface carries a single tooth on the sub-apical area, interpreted as a half-pegma, and one or two teeth on the supra-apical surfaces adjacent to the dorsal hinge zone, the latter may be elongated and both may be divided. The teeth are represented by pits on the internal mould.

Description. - The shell exterior of Pseudomyona queenslandica was described by Gubanov et al. (2004) on the basis of silicified specimens from the Kuonamka Formation (Fig. 4). The shell exterior is not known in available material from Australia and Greenland. The shell is bilaterally symmetrical along the dorsal line, pseudobivalved, D-shaped in lateral view with the straight dorsal hinge line interrupted by a swollen early growth stage located at about one third of the distance from the subapical margin to the supra-apical margin (Fig. 4A, B, J). The ventral margin varies from almost hemispherical (Fig. $4 \mathrm{~J})$ to asymmetric with tapering towards the supra-apical margin and with the greatest height developed below the early growth stage (Fig. 4A).

The early growth stage is elongate, tapering towards the supra-apical margin (Fig. 4F, H, K). It is asymmetric in lateral profile (Fig. 4D) with a more shallowly sloping supra-apical surface and a steeper sub-apical surface that may be concave (Fig. 4I, J). It is strongly convex in transverse profile such that it overhangs the adjacent lateral shell surfaces (Fig. 4E), the junction being marked by a pronounced groove that may continue around the supraapical termination. The sub-apical surface of the dorsum is marked by a prominent carina of the same transverse width as the early growth stage, into which it grades abruptly (Fig. 4G, H). The carina is the locus of a gape in the subapical margin (Fig. 4F) that is parallel-sided close to the dorsum (Fig. 4F) and is traversed by fine, continuous, comarginal growth lines (Fig. 4G). On the supra-apical surface, the dorsum is angulated without apparent interruption of the crossing growth lines; a narrow gape may be present at the junction with the ventral surface Preservation of this region is poor, however, and the crest of the angulation is often disrupted by diagenetic fractures (Fig. 4B). Ornamentation consists of comarginal growth lines that may be slightly rugose. Partially exfoliated specimens show widely spaced radial ribs traversing the growth lines, the ribs becoming more abundant and more closely spaced near the margins (Fig. 4A, C).

As with the Australian material described by Runnegar \& Jell (1976), Runnegar (1983), Runnegar \& Pojeta (1992) and Hinz-Schallreuter (1995, 2000), all specimens from North Greenland are internal moulds. Their length:width ratio is about 1.6 (Fig. 5). In contrast to the smooth exterior of the supra-apical surface of the Kuonamka material (Fig. 4), this surface of the internal mould carries two prominent ridges that originate one on each side of the early growth stage below the groove that forms the junction between the early growth stage and the lateral areas of the shell (Fig. 5A-C). These ridges delimit a concave area along the median line of the dorsum immediately adjacent to the early growth stage before coalescing into a single ridge at about half the distance to the supra-apical margin. On the sub-apical surface the angular margins of the upper surface of the carina pass into ridges on the lateral areas of the early growth stage that lie above the groove at the junction between the early growth stage and the lateral areas of the shell (Fig. 5B, C). In apical view (Fig. 5B, C) the transverse profile of the supra-apical surface is seen to be narrow and acute, whereas the carina on the sub-apical surface is broad, with a flattened upper surface. 


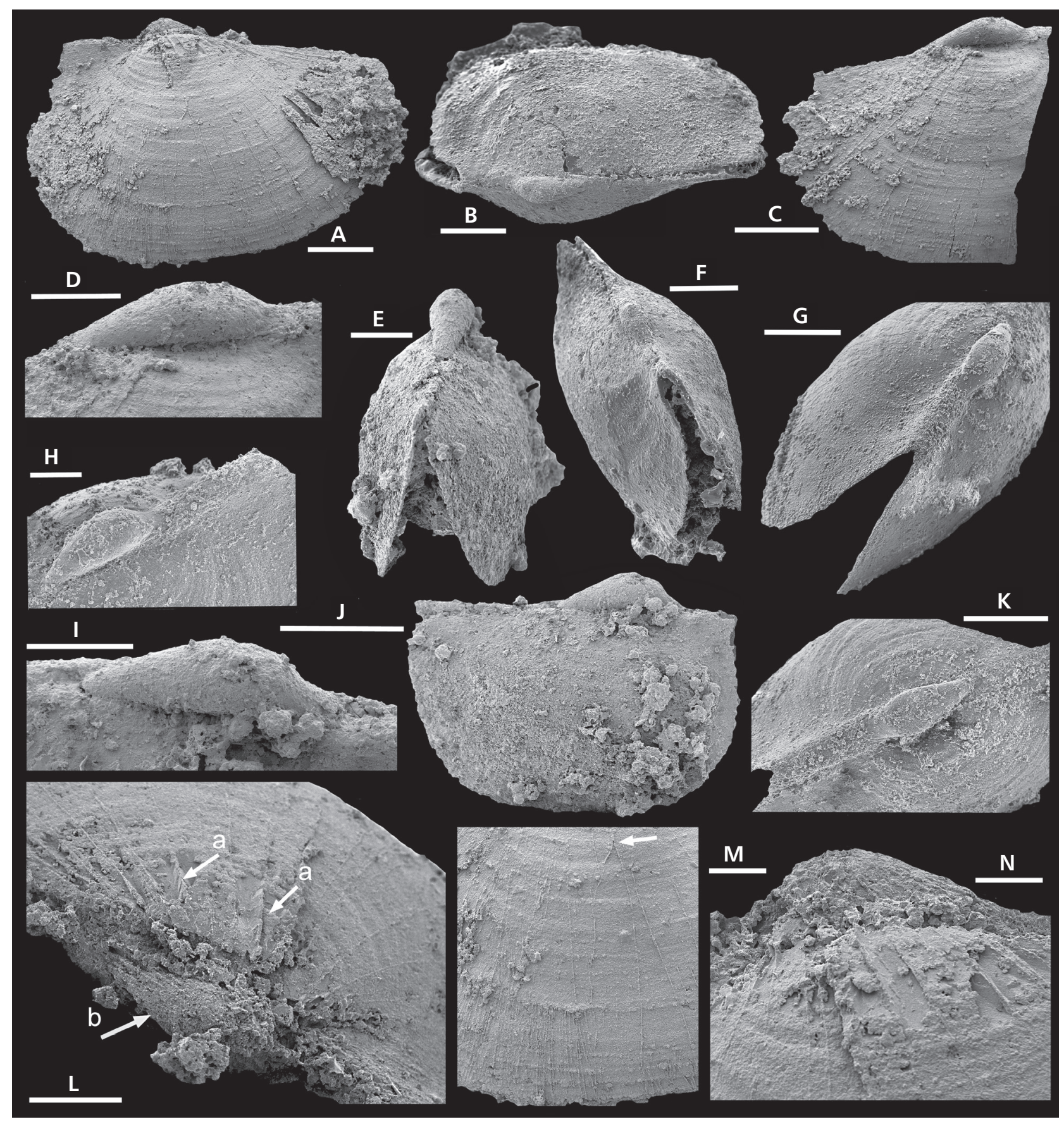

Figure 4. Silicified specimens of Pseudomyona queenslandica (Runnegar \& Jell, 1976) from the Kuonamka Formation of northern Siberia; Miaolingian Series, Drumian Stage. A, L-N - SMNH 160599 showing radial ridges crossing comarginal growth lines; A, N - lateral view, with detail of apex (N); L - apico-lateral view showing stacked arrow-head crystals culminating at the ridges (arrow a) and fine ridges (arrow b) on the early growth stage; $\mathrm{M}$ - detail of ventral margin showing bifurcating ridge (arrow). B, F - SMNH 160602, apico-lateral view (B) showing diagenetic fracture along dorsal area; sub-apical view (F) showing gape. C, D - SMNH 160600, lateral view (C) with detail of early growth stage (D). E, I, J - specimen associated with SMNH 160598-160600, supra-apical surface (E), lateral view (J) with detail of early growth stage (I). G, H, K - SMNH 160598, subapical surface and gape $(\mathrm{G})$ with growth lines crossing carina $(\mathrm{G})$; early growth stage and carina on sub-apical surface $(\mathrm{H}, \mathrm{K})$. Scale bars: $50 \mu \mathrm{m}(\mathrm{N})$; $100 \mu \mathrm{m}(\mathrm{D}, \mathrm{E}, \mathrm{H}, \mathrm{I}, \mathrm{L}, \mathrm{M}) ; 200 \mu \mathrm{m}$ (A-C, F, G, J, K). Images: Alexander Gubanov.

At the junction between the early growth stage and the sub-apical surface, in lateral view, a deep pit is present on each lateral surface below the carina (Fig. 5A, C, E, I, arrows a). The pits correspond to teeth on the shell interior and are variable in shape within available material. In a similar perspective, paired pits are also present on the lateral surfaces of the shell at the point where the ridges on the supra-apical surface coalesce (Fig. 5C, E, arrows b). 
The pits are elongated subparallel to the crest of the dorsum and may be divided (Fig. 5E-H, J).

Discussion. - Specimens of Pseudomyona queenslandica from North Greenland and Australia show variation in the form of the pits on the internal mould. Those on the sub-apical surface are usually deeper in the Greenland material and are interpreted as representing half-pegmas, elements of a pegma that are not continuous across the median plane from one lateral surface to the other (Fig. $4 \mathrm{~A}, \mathrm{E})$. Pits on the supra-apical surface form an elongated depression of variable form, which extends upto about half of the distance from the early growth stage to the margin.

Details of shell structure of the shell interior or muscle scars described by Runnegar (1983) and Runnegar \& Pojeta (1992) are not preserved on the internal moulds from the Ekspedition Bræ Formation. Preservation of the shell surface is discussed below.
Occurrence. - Miaolingian Series, Drumian Stage, of Queensland, northern Siberia and North Greenland.

\section{Pseudomyona groenlandica sp. nov.}

Figures 6-8

Holotype. - PMU 37511 from GGU sample 315006 (Fig. $6 \mathrm{~A}-\mathrm{H}$ ), south-west side of glacier feeding into the head of Navarana Fjord, south-east Freuchen Land, North Greenland (Fig. 2A).

Paratypes. - PMU 37512-37515 from the same sample and locality as the holotype.

Type horizon and locality. - Fimbuldal Formation (Fig. 2B), south-west side of glacier feeding into the head of Navarana Fjord, south-east Freuchen Land, North Greenland (Fig. 2A). Cambrian, Miaolingian Series, Drumian Stage.

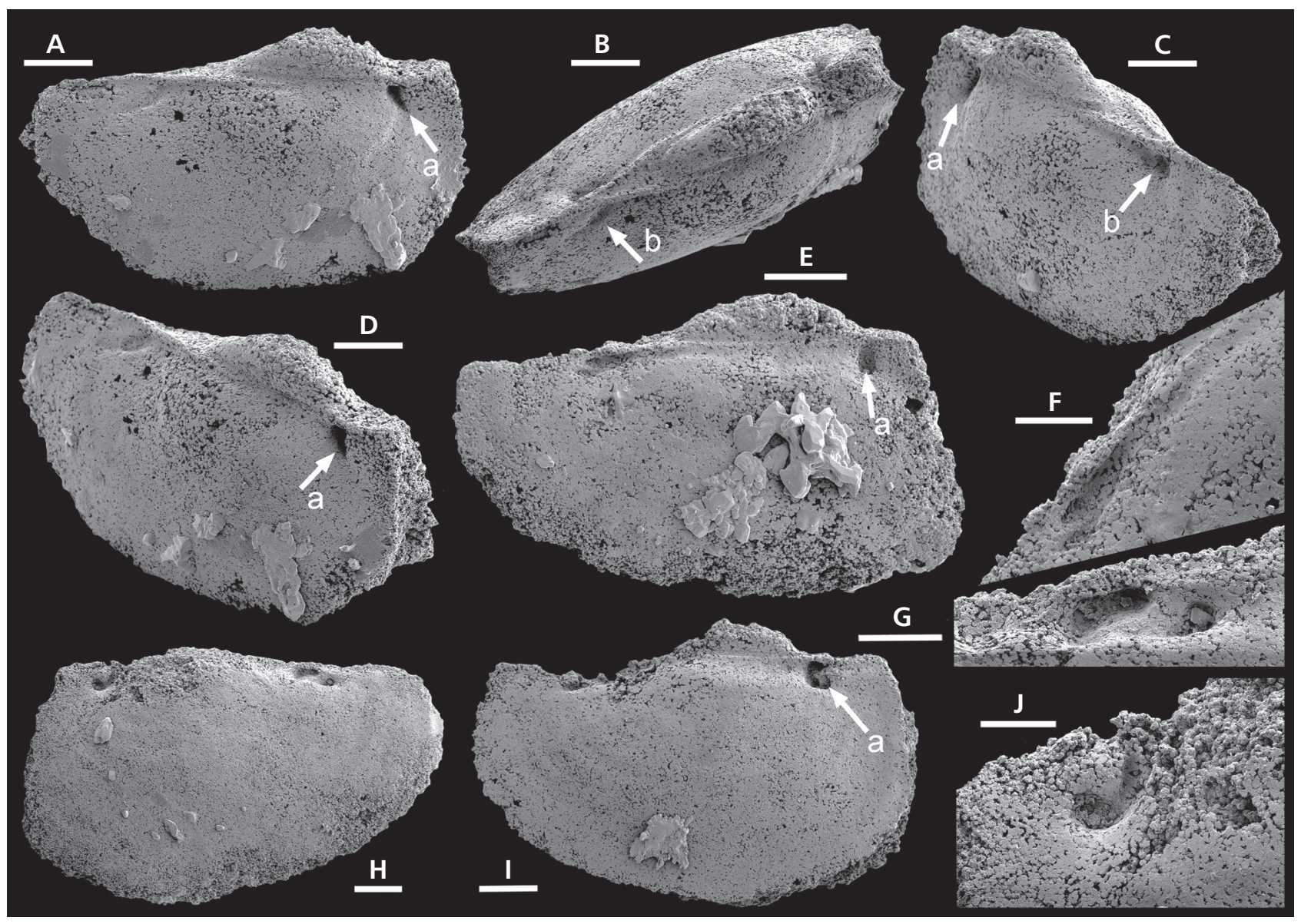

Figure 5. Pseudomyona queenslandica (Runnegar \& Jell, 1976), internal moulds from GGU sample 271493, Ekspedition Bræ Formation, Lauge Koch Land, North Greenland, Miaolingian Series, Drumian Stage. A-D - PMU 37507, lateral view (A); dorsal view (B); dorso-lateral view (C); dorsolateral view (D). E, F - PMU 37508, lateral view (E) with detail of bifurcating supra-apical pit (F). G, H, J - PMU 37509, lateral view (H) with detail of supra-apical (G) and sub-apical (J) pits. I - PMU 37510, lateral view. Symbols: arrow a - prominent sub-apical pits; arrow b - supra-apical pits. Scale bars: $50 \mu \mathrm{m}(\mathrm{F}, \mathrm{G}, \mathrm{J}) ; 100 \mu \mathrm{m}(\mathrm{A}-\mathrm{E}, \mathrm{H}, \mathrm{I})$. 
Material. - In addition to the illustrated specimens, a few fragments also from GGU sample 315006.

Etymology. - From Greenland (Danish, Grønland).

Diagnosis. - Species of Pseudomyona in which the dorsal hinge zone carries a dominant peg-like tooth on each side of the sub-apical surface (half-pegma) and a series of interdigitating peg-like hinge teeth extending along the length of the supra-apical surface. The teeth are represented by pits on the internal mould.

Description. - All specimens from North Greenland are internal moulds, which form the basis of the following description. Length:width ratio is about 1.5. In lateral view the specimens are wedge-shaped, tapering towards the supra-apical margin (Fig. 6B, D), with a straight hinge zone developed on either side of the swollen early growth stage; the highest point of this earliest growth stage is located at about one third of the distance from the subapical to the supra-apical margin. The sub-apical ventral margin is shallowly concave immediately below the hinge zone but quickly becomes convex such that the shell attains maximum height below the early growth stage. Thereafter, the margin is straight before increasing in curvature towards the supra-apical margin (Fig. 6B, D). A broad gape is present in the sub-apical area, narrowing along the ventral margin towards the supra-apical margin. The lateral surfaces of the internal mould are marked by subdued comarginal corrugations.

The supra-apical surface of the internal mould carries a prominent ridge on each side of the early growth stage below the groove that forms the junction between the early growth stage and the lateral areas of the shell exterior (Fig. 6A-C). A concave area is formed between the ridges along the median line of the dorsum immediately adjacent to the early growth stage before they join together into a single ridge at about half the distance to the supra-apical margin. This single ridge becomes less prominent towards the margin in some specimens (Fig. 8). The sub-apical surface carries two ridges at the junction between the dorsum and the lateral areas of the early growth stage that mainly lie above the groove at the junction between the early growth stage and the lateral areas of the shell (Fig. $6 \mathrm{~A}, \mathrm{I}$ ). In apical view (Fig. 6E), the transverse profile of the supra-apical surface is narrow and acute compared to the sub-apical surface, which is broad, with a flattened upper surface (Figs 6E, 7A).

In lateral view (Fig. 6A, B, D), a deep pit is present on each lateral surface at the junction between the early growth stage and the sub-apical surface, below the carina. The pits were produced by prominent tooth-like structures on the shell interior and may be accompanied by a second, smaller, pit (Fig. 8D). A row of pits is also present on the lateral surfaces of the shell from the early growth stage to the supra-apical margin. As many as 11 pits produced from teeth on each lateral surface of internal moulds have been observed (Fig. 8A, E), interdigitating with those on the opposite lateral surface (Fig. 6E, H).

Discussion. - Pseudomyona groenlandica is distinguished from Pseudomyona queenslandica by the proliferation of hinge teeth along the supra-apical surface. Only a few teeth are present in the latter, close to the early growth stage (Fig. $5 \mathrm{H}$ ), whereas a row of teeth extends from the early growth stage to the supra-apical margin in Pseudomyona groenlandica (Fig. 8E).

Occurrence. - Known only from the type locality in Freuchen Land, North Greenland (Fig. 2A).

\section{Morphology and function}

Contrasting styles of preservation in specimens from Australia, Greenland and Siberia establish a clear picture of the morphology of Pseudomyona. Silicified specimens from the Kuonamka Formation of northern Siberia (Gubanov et al. 2004) illustrate the ornamented outer surface and also details of the periostracum (Fig. 4). Phosphatic internal moulds from Australia and Greenland provide a detailed picture of the morphology of the internal surface of the shell and its hinge structures (Figs 5-8). Australian material also replicates details of shell microstructure (Runnegar 1983; Vendrasco et al. 2010, 2011a, b) not preserved in Greenland specimens.

\section{Periostracum in Pseudomyona queenslandica}

A combination of possible exfoliation, recrystallisation and partial silicification seems to be responsible for the preservation of the radial ribs present on the outer surface of some of the specimens of Pseudomyona queenslandica from the Kuonamka Formation of Siberia. Comarginal growth ornamentation in most available specimens is subdued, but the growth lines are preserved in fine detail in two illustrated specimens that have clearly been partially exfoliated prior to silicification, or differentially silicified (Fig. 4A, C, M). In SMNH 160599, the outermost shell layer is lacking, represented by a gap beneath the outer encrustation of the shell (Fig. 4A, right side). Radial ribs overlie and traverse the comarginal growth lines on the preserved surface. The ribs are narrow and widely spaced in SMNH 160599 (Fig. 4A), but become closely spaced near the ventral margin and along the sub-apical carina (Fig. 4A, C, M). Rarely, two adjacent ribs coalesce (Fig. $4 \mathrm{M}$, arrow). 


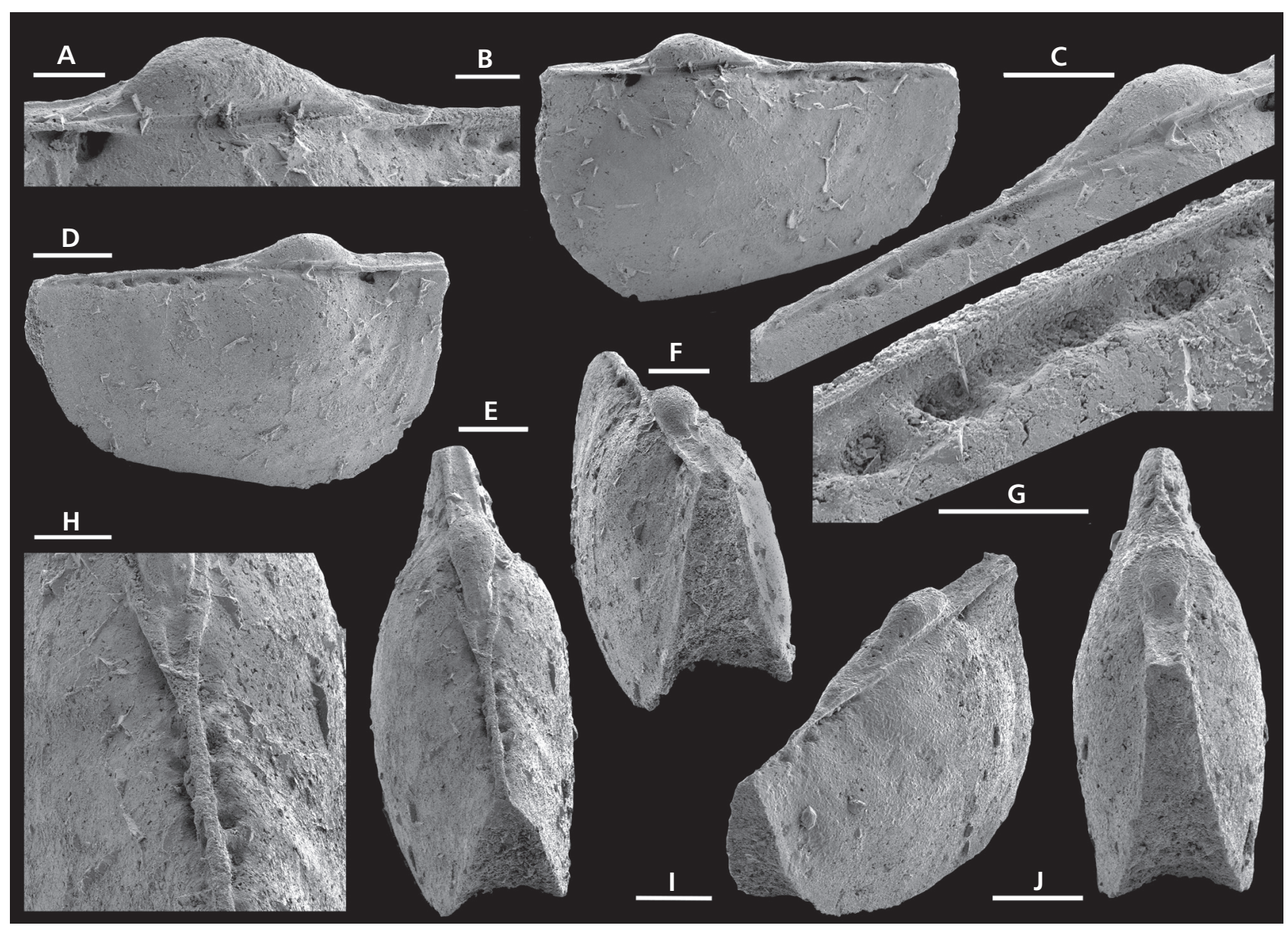

Figure 6. Pseudomyona groenlandica sp. nov., internal moulds from GGU sample 315006, Fimbuldal Formation, Freuchen Land, North Greenland, Miaolingian Series, Drumian Stage. A-H - PMU 37511, holotype, lateral view (B) with detail of early growth stage (A); lateral view (D) with detail of pits on supra-apical surface $(\mathrm{C}, \mathrm{G})$; oblique dorsal view (E) with interdigitating pits on supra-apical surface (detail in $\mathrm{H})$; sub-apical surface (F). I, J - PMU 37512, oblique dorso-lateral view (I); oblique dorsal view of sub-apical carina (J). Scale bars: $50 \mu \mathrm{m}$ (A, C, G, H); $100 \mu$ m (B, D-F, I, J).

In the apical region of SMNH 160599 (Fig. 4A), the ribs are seen to represent the crest of rows of steeply inclined, imbricated, arrow-head crystals deeper in the shell (Fig. 4L, arrows a). Fine ridges are also present on the early growth stage (Fig. 4L, arrow b). Similar structures are present in silicified specimens of Anabaroconus sibiricus Gubanov, Kouchinsky, Peel \& Bengtson, 2004 from the same sample from the Kuonamka Formation (Gubanov et al. 2004, fig. 5n, u) and were also described by Vendrasco et al. (2011b, fig. 5.18) in Mellopegma georginense Runnegar \& Jell, 1976 from the Miaolingian of Australia. They are also illustrated herein in the apical area of Yochelcionella ostentata Runnegar \& Jell, 1976 from the basal Kuonamka Formation, Cambrian Series 2, Stage 4, of northern Siberia (Gubanov et al. 2004; Fig. 1E, F).

Vendrasco et al. (2011b) suggested that the radial ridges represent mineralised traces of the periostracum, the outermost, proteinaceous layer in the mollusc shell, which forms the template for crystallisation of the underlying calcium carbonate. This interpretation is supported here, not least on account of the pristine comarginal ornamentation preserved on the underlying shell surface (Fig. 4A, C, M). Harper (1997) noted that the periostracum in present day Bivalvia varies greatly in thickness; while often very thin, it may exceed $100 \mu \mathrm{m}$. While its under surface is a precise template for the growing shell, the outer surface is often smoother, with a subdued reflection of growth lines. This difference is visible here when comparing the sub-periostracal shell surface with the outer preserved surface in silicified specimens from Kunonamka (Fig. 4). However, it is premature to suggest that the smoothed outer surface (Fig. 4B, J, K) is silicified periostracum since this outer proteinaceous layer is often quickly lost in present day molluscs; corrosion or weathering of the outer shell layer may also subdue expression of the growth lines.

The function and original composition of the radial ridges are not known, although some compositional difference from the overlying (and missing in Fig. 4A, C, M) proteinaceous layer is implied by their preservation. 
Calcium carbonate is often disseminated within the periostracum of recent bivalves as small spicules (Carter \& Aller 1975, Harper 1997, Checa et al. 2014) but ridges or canals of the type preserved here have not been recorded. Near the margin, the ridges become more numerous and closely packed, with new ridges introduced at slightly more prominent comarginal growth lines (Fig. 4M). In addition to the comarginal growth lines, the underlying surface preserves a finely dimpled pattern also seen on some internal moulds from the Greenland samples (Fig. 7E).

Close study of the dorsal area of SMNH 160599 (Fig. $4 \mathrm{~L}, \mathrm{~N}$ ) indicates that a variety of diagenetic processes has occurred. Due to incomplete silicification, the radial ridges are seen to represent the locus of the acute tips of stacked, arrow-head crystals oriented with their axes perpendicular to the shell surface but within the preserved shell layer, i.e. below the supposed periostracum, which is not preserved by material other than the radial ridges. The spar crystals seemingly indicate recrystallisation of the calcareous shell prior to silicification, but why these crystals are closely associated with the radial ridges is not known. The same structure is evident in illustrations of co-occurring specimens of the cap-shaped helcionelloid Anabaroconus sibiricus Gubanov, Kouchinsky, Peel \& Bengtson, 2004 from the upper Kuonamka Formation (Gubanov et al. 2004, fig. 5n, u).

\section{Hinge teeth and half-pegmas}

Pits along the dorsal margin are characteristic of internal moulds of Pseudomyona. In Pseudomyona groenlandica, the development of a series of pits along the supra-apical surface of each lateral area (Figs 6C, E, G, H; 8A, E) is a clear indication of interlocking hinge teeth comparable to those seen in Tuarangia (Fig. 9) and many recent bivalves (Ponder et al. 2020). A series of hinge teeth of this kind is not developed in Pseudomyona queenslandica where a shallow pit or pits is present just beyond its supraapical end (Fig. 5C, E, arrows with bar).

A deep pit is present on each lateral surface at the sub-apical end of the early growth stage of Pseudomyona queenslandica (Fig. 5C, E, I, arrows a) and in Pseudomyona groenlandica (Figs 6A, 8D). These pits were formed by teeth that do not interlock across the median line but are juxtaposed against each other (Fig. 5B). As such, they do not serve to prevent translation of the lateral areas against each other, as do the interlocking teeth, but may function as paired buttresses to prevent the compaction of the lateral areas of the shell with contraction of adductor muscles. Together, these opposing sub-apical teeth, termed half-pegmas (Fig. 3A), function as a pegma, the diagnostic character of Class Rostroconchia (Pojeta \& Runnegar 1976, Wagner 1997).
When in contact, the separate half-pegmas together form an anvil against which adductor muscles can bend the elastic lateral areas of the shell (Runnegar 1983) when closing the ventral margin. On relaxation of the muscles, the same elasticity and possible hydrostatic adjustment from the adductor muscles opens the ventral margin. This is also the case with a transversely complete pegma, as in rostroconchs (Pojeta \& Runnegar 1976), but the latter also inhibits the degree of flexing of the shell along the hinge that is possible in Pseudomyona.

Most rostroconch pegmas are continuous transverse structures between the two lateral surfaces that provide increased stability, but they must be physically reformed to permit growth of the shell when opposing ventral margins come in contact. Pojeta \& Runnegar (1976) describe frequent shearing and fracturing in the hinge zone as the lateral areas add new shell material at the ventral margin. The half-pegmas in Pseudomyona do not form a continuous structure from one lateral surface to the other, but occur as opposing, separate, teeth. Contraction of the adductor musculature brings the half-pegmas of each pair into contact. Their separation on muscle relaxation in the present material better allows the shell to grow without the cleavage and fracturing reported by Pojeta \& Runnegar (1976), although the present halfpegmas may become conjoined in larger shells.

The half-pegmas of Pseudomyona are viewed as an independent (or incipient) stage in pegma development. It may seem more logical to regard half-pegmas as a degradation of the full pegma condition of ribeirioid and other rostroconch groups, resulting from increased dorsal hinge development. Thus, they are not present in Tuarangia, which is considered to be a descendant of Pseudomyona, where they would serve no purpose in the bivalved form. At the present time, however, suitable pegma-bearing ancestors to Pseudomyona are not known from older Cambrian strata.

The presence of a pegma is the defining character of the Rostroconchia. Thus, the opposing half-pegmas of Pseudomyona, if interpreted as an incipient pegma, may suggest that Pseudomyona is the earliest rostroconch. However, the mechanical stabilisation of the subapical area by a transverse structure can take several forms, depending upon shell morphology, such that the acquisition of a pegma or pegma-like structures probably represents analogous rather than homologous developments. Enigmaconcus MacKinnon, 1985 from the Guzhangian Tasman Formation of New Zealand and Nyeboeconus Peel, 1994 from the Drumian Henson Gletscher Formation of North Greenland have wider, relatively tall, cap-shaped, shells in which the transverse pegma is located low on the sub-apical surface (MacKinnon 1985, Peel 1994). Eurekapegma MacKinnon, 1985, also from the Tasman Formation, has a strongly 


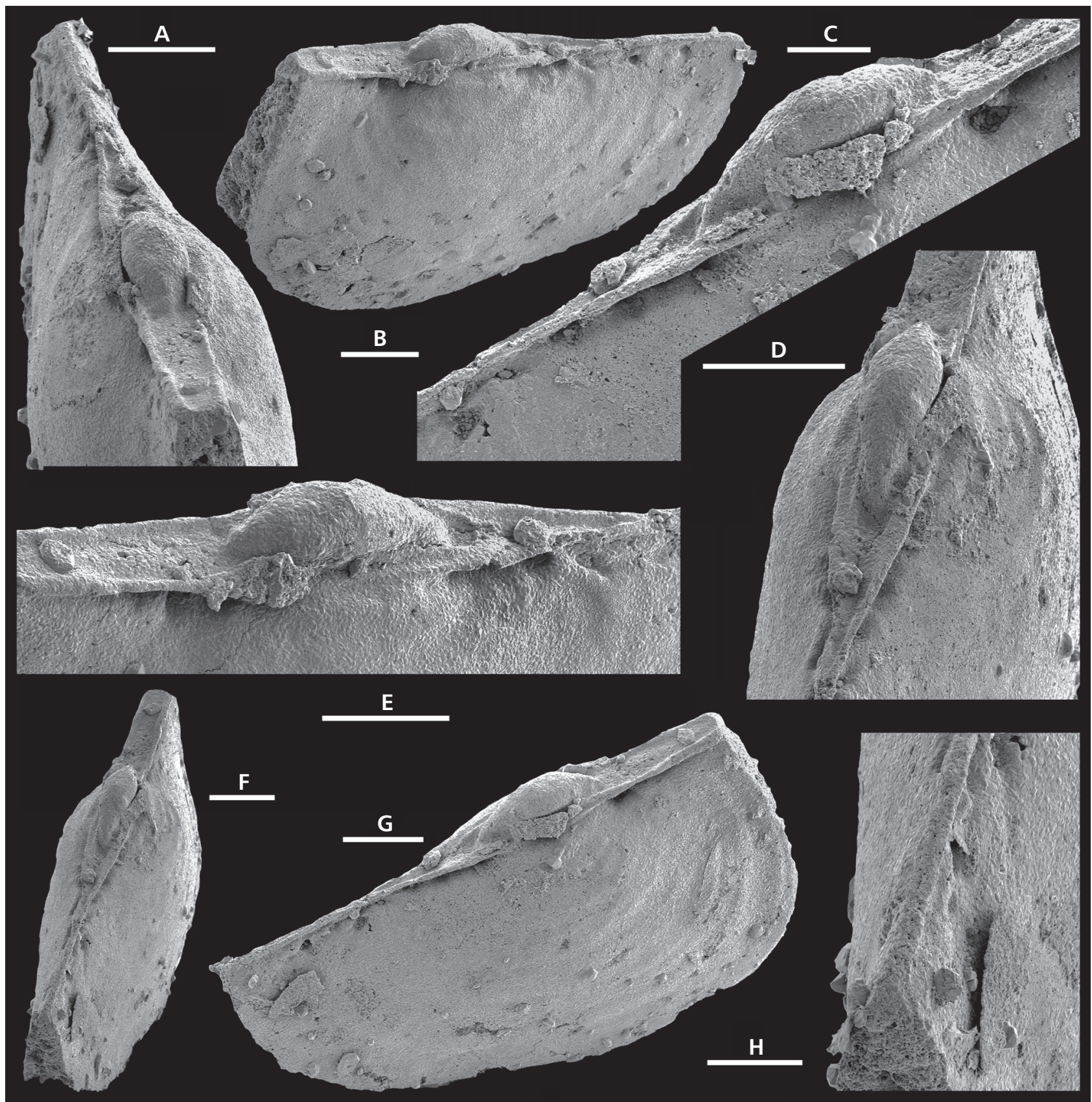

Figure 7. Pseudomyona groenlandica sp. nov., internal moulds from GGU sample 315006, Fimbuldal Formation, Freuchen Land, North Greenland, Miaolingian Series, Drumian Stage. A-H - PMU 37513, oblique dorsal views (A, F) with detail of supra-apical termination (H); oblique dorso-lateral views (B, G), early growth stage (C-E). Scale bars: $100 \mu \mathrm{m}(\mathrm{A}, \mathrm{B}, \mathrm{D}-\mathrm{G}), 50 \mu \mathrm{m}(\mathrm{C}, \mathrm{H})$.

laterally compressed shell closely similar in shape to Mellopegma, although some specimens (Fig. 10) show considerable allometry in their growth style reminiscent of the yochelcionellid Eotebenna viviannae (Fig. 1H). Eurekapegma develops a prominent, internal, transverse plate, termed the zygion by MacKinnon (1985), extending almost to the ventral margin, but not present immediately below the dorsal crest (MacKinnon 1985, fig. 7), as is also the case in Pinnocaris lapworthi Etheridge, 1878 from the Ordovician of Scotland (Peel 2004; Fig. 1B, C). MacKinnon (1985) and Vendrasco et al. (2011b) considered Eurekapegma to be a possible descendant of $\mathrm{Mel}$ lopegma.

A pegma was stated to be present in Watsonella by Pojeta \& Runnegar (1976) as the oldest rostroconchs, but studies by MacKinnon (1985), Li et al. (2011), Devaere et al. (2013), Kouchinsky et al. (2017) and Guo et al. (2021) have rejected this interpretation. However, the 
rapid change of direction between the supra-apical and sub-apical surfaces, in lateral view (Fig. 1J), in this and other laterally compressed Cambrian univalves may perform a similar strengthening function as a separate pegma. Other taxa, such as Anabarella australis Runnegar in Bengtson et al. (1990), develop a deep cleft on the sub-apical surface at the transition to the sub-apical fold (Bengtson et al. 1990, Peel 1991a, Parkhaev 2001).

\section{The flexible hinge of Pseudomyona}

The longitudinal ridges along the dorsum of internal moulds of Pseudomyona are not seen on the outer surface, although their position on the sub-apical surface is indicated by the angular edges of the carina (Figs 3B; 6E, F; 7A, B). The ridges are not continuous along the entire length of the dorsal surface but form separate sub-apical and supra-apical systems that overlap on the lateral areas of the early growth stage (Figs $5 \mathrm{~A}-\mathrm{C}, 6 \mathrm{~A}-\mathrm{D}$ ), clearly an accommodation of the presence of this growth stage to the overall hinge function along the dorsal surface. Adjacent to the early growth stage and on the sub-apical surface, the ridges represent channels on the shell interior and are often parallel-sided with a sharp, right-angled junction with the flattened upper surface (Figs 5B, 6E, 7D). Distally, on the supra-apical surface, the ridges coalesce to a single median ridge or angulation (Figs $6 \mathrm{H}, 7 \mathrm{H}, 8 \mathrm{E}$ ).

The width of the ridges reflects the degree of opening of the individual specimens, as preserved. Ridges are often inconspicuous where the lateral areas of the shell are closed together (Fig. 8) and more prominent, wider, in specimens where the lateral areas show a large anterior gape (Figs 3B; 6E, F). There may be some slight diagenetic influence in both situations, for example where the ridge is maintained between the interdigitating teeth on the supraapical surface (Fig. 6E, H), although this may just be due to increased gape. There is no direct evidence of the presence of a discrete ligament(s) within the channels on the shell interior. The smooth exterior of silicified specimens (Fig. 4G, K) suggest that an elastic outer shell layer and a thickened periostracum formed the hinge. The groove separating the early growth stage from the lateral areas on the external surface of silicified specimens (Fig. 4D, I) is the only indication of movement in the dorsal area. Its presence reflects the opposite mechanical moment of movement to that experienced across the dorsum, distant from the early growth stage, with opening or closing.

\section{Evolutionary relationships}

The lower three series of the Cambrian (Terreneuvian, un-named Cambrian Series 2, and Miaolingian) contain a morass of small cap-shaped univalve shells that generally exhibit few features useful for their classification. Runnegar \& Jell (1976) grouped many of these into an embracive Class Monoplacophora Wenz in Knight, 1952 and Class Rostroconchia was introduced by Pojeta et al. (1972) for pseudo-bivalved molluscs (Pojeta \& Runnegar 1976). Peel (1991a) avoided using Monoplacophora and proposed a distinction between exogastric tryblidian forms, which he assigned to the Class Tergomya Horný, 1965, and endogastric shells placed within a Class Helcionelloida Peel, 1991b. Both these approaches, most recently reviewed by Guo et al. (2021), fail to reflect the complexity of Cambrian mollusc evolution. Parkhaev (2002, 2008, 2017, 2019; Parkhaev in Bouchet et al. 2017) developed a different approach but a generally accepted overview of Cambrian groups remains elusive.

\section{Pseudomyona and Mellopegma}

The origin of Pseudomyona is unclear. With regard to the degree of lateral compression and curvature of the ventral margin, Pseudomyona is similar to Mellopegma (Figs 1I, 10) and Vendrasco et al. (2011b) suggested that stenothecids such as Mellopegma may have been ancestral to rostroconchs. However, the lateral compression and curved aperture might be expected in any helcionelloid adapting to an infaunal life, as pointed out by Peel (1991a), Waller (1998) and Gubanov et al. (1999), while narrowing of the aperture also represents a simple antipredator defensive strategy in univalved molluscs (Vermeij 1987, Vendrasco et al. 2011b). The straight dorsum of Pseudomyona (Fig. 1A) contrasts strongly with the longitudinally convex supra-apical dorsum of Mellopegma (Fig. 1I), the latter also lacks any indication of a dorsal hinge zone or hinge teeth. The ontogenetic change in coiling and shell expansion in Pseudomyona, witnessed by its upright early growth stage, finds no parallel in elongate species of Mellopegma, where the initial growth stage is often lower than the crest of the dorsum and overhangs the sub-apical surface (Vendrasco et al. 2011b). However, similar profound asymmetry of the logarithmic spiral of the expanding shell is seen in the unrelated elongate yochelcionellid Eotebenna viviannae (Fig. 1H) and in some specimens of Eurekapegma cooperi MacKinnon, 1985 (Fig. 10) of similar age, both of which are also characterised by strong lateral compression.

In North Greenland, Mellopegma is known from the Henson Gletscher Formation to the Fimbuldal Formation (late Stage 4-Drumian; Fig. 2B). It occurs together with Pseudomyona groenlandica in GGU sample 315006 where their dissimilar styles of preservation suggest some differences in shell composition. Mellopegma is preserved as phosphatic coatings of the shell exterior and 


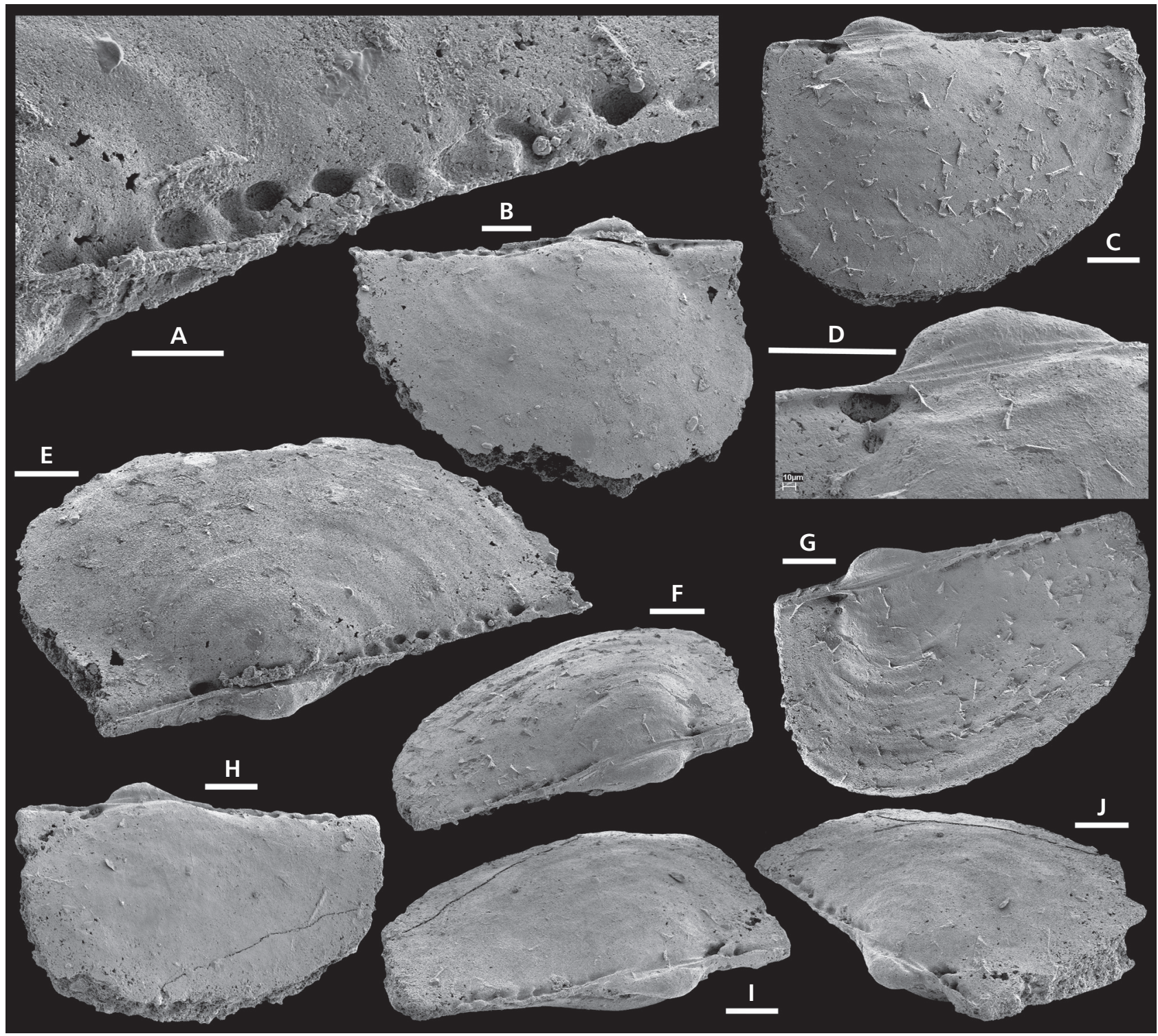

Figure 8. Pseudomyona groenlandica sp. nov., internal moulds from GGU sample 315006, Fimbuldal Formation, Freuchen Land, North Greenland, Miaolingian Series, Drumian Stage. A-G - PMU 37514, lateral views (B, C, G) with detail of early growth stage (D); dorso-lateral views (E, F) with detail of hinge teeth pits (A). H-J - PMU 37515, lateral (H) and dorso-lateral (I, J) views. Scale bars: $50 \mu \mathrm{m}$ (A); $100 \mu \mathrm{m}$ (B-J).

interior surfaces (Fig. 1I) while Pseudomyona is known only as internal moulds (Figs 6-8). Internal moulds of Pseudomyona show no trace of the small tubercles that occur on internal moulds of Mellopegma (Vendrasco et al. 2011b).

\section{Pseudomyona and Tuarangia}

Tuarangia was proposed by MacKinnon (1982), with type species Tuarangia paparua MacKinnon, 1982 from the Tasman Formation at Trilobite Rock, Cobb Valley, South Island, New Zealand (Miaolingian Series, Guzhangian Stage, Boomerangian Local Stage, Ptychagnostus cassis
Biozone). Known from abundant internal moulds, it was classified as Class Bivalvia, Order Tuarangiida nov. by MacKinnon (1982) on account of the bivalved shell and straight hinge line, with numerous teeth disposed either side of a short amphidetic ligament. Runnegar \& Bentley (1983) rejected the assignment to Bivalvia, suggesting that Tuarangia was a 'quasirostroconch' or bivalved monoplacophoran similar to Pseudomyona queenslandica. Runnegar (1983) considered the median apical ridge of Tuarangia to be the scar of a broken off early growth stage (Fig. 9B, C, E), but this was refuted by MacKinnon (1985) who restated his opinion that the scar was formed by a ligament, and that Tuarangia was a bivalve. Additionally, MacKinnon (1985) rejected the notion that 


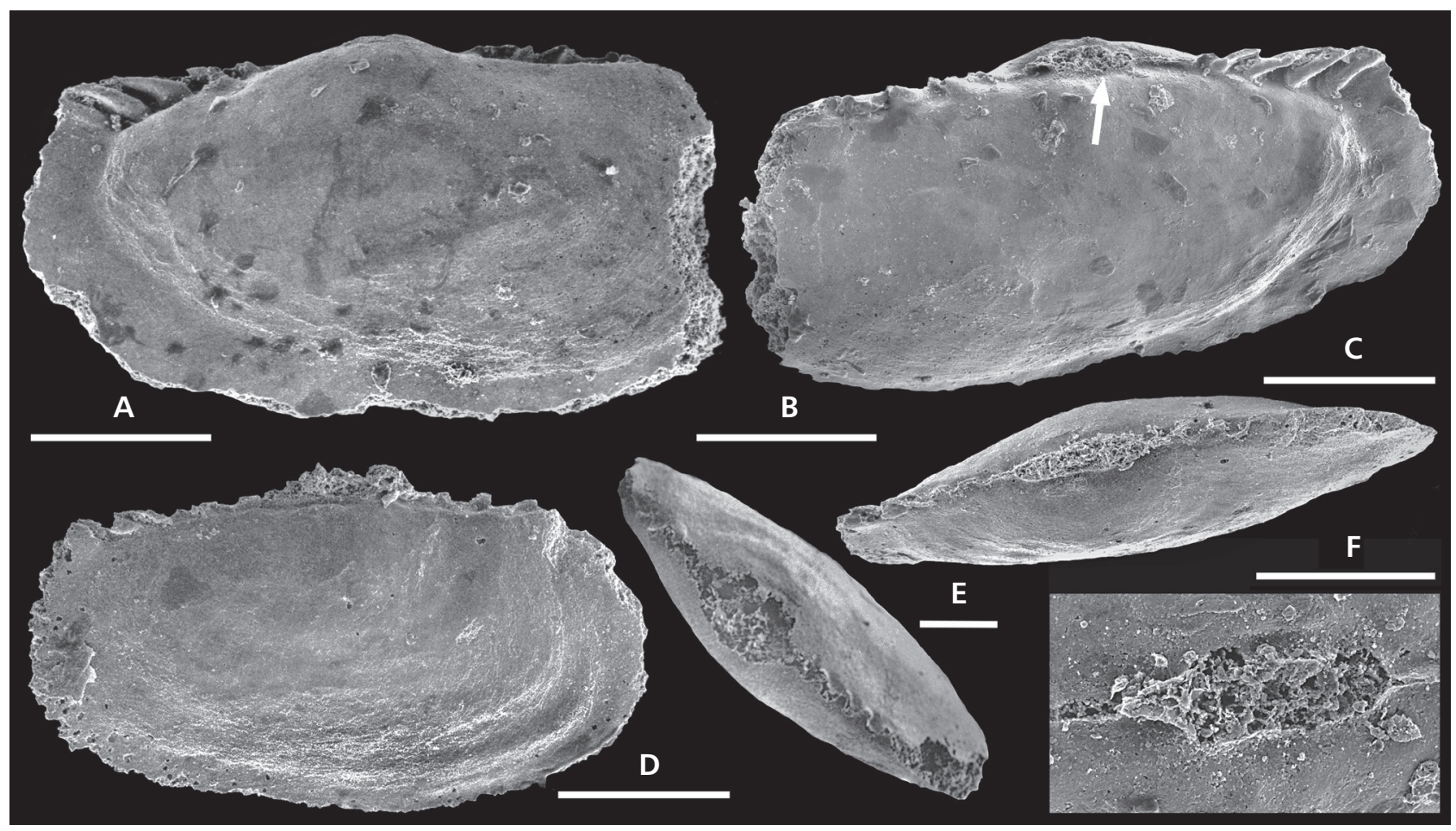

Figure 9. Tuarangia from Denmark and Poland • A-D, F - Tuarangia gravgaerdensis Berg-Madsen, 1987, internal moulds, Andrarum Limestone, Bornholm, Denmark, Miaolingian Series, Guzhangian Stage; holotype (A, B, F), MGUH 17.451, lateral view of left valve (A), dorso-lateral view of right valve with arrow locating ligament scar (B) and scar of ligament (F); paratype (C, D), MGUH 17.452, dorsal view showing ligament scar and interdigitating hinge teeth $(\mathrm{C})$ and lateral view of left valve (D) • E - Tuarangia sp., glacial erratic, northern Poland, Collections of Zakład Paleobiologii, PAN, Warszawa, Poland. Scale bars: $200 \mu \mathrm{m}$ (A-E), $80 \mu \mathrm{m}$ (F). Images: Jerzy Dzik (E), otherwise Vivianne Berg-Madsen.

bivalves were descended from rostroconchs, suggesting that they were derived directly from monoplacophorans. Tuarangia, however, was considered to be probably closely related to Pseudomyona (MacKinnon 1985).

In proposing a second species, Tuarangia gravgaerdensis, based on internal moulds from the Andrarum Limestone bed (Alum Shale Formation) of Bornholm, Denmark (Guzhangian Stage, Solenopleura brachymetopa Biozone, placed within the global Lejopyge laevigata agnostoid Biozone by Axheimer et al. 2006), BergMadsen (1987) maintained the interpretation of Tuarangia as a pteriomorph bivalve (Fig. 9). Runnegar \& Pojeta (1992) concluded that Pseudomyona and Tuarangia belonged to the same clade but were not true bivalves.

Hinz-Schallreuter (1995) described Tuarangia gravgaerdensis tenuiumbonata from the Exsulans Limestone bed (Alum Shale Formation) of Bornholm, Denmark (Wuliuan Stage, Ptychagnostus gibbus Biozone), including internal moulds and specimens with the exterior and inner surfaces preserved. However, Hinz-Schallreuter (2000) subsequently re-interpreted the same material as being derived from the Andrarum [Limestone] Breccia. Thus, Tuarangia gravgaerdensis tenuiumbonata and other bivalves that Hinz-Schallreuter $(1995,2000)$ described from the same samples (Pojetaia ostseensis Hinz-
Schallreuter, 1995 and Camya asy Hinz-Schallreuter, 1995) are not derived from the Exsulans Limestone (Wuliuan Stage) but are from essentially the same horizon (Andrarum Limestone; Guzhangian Stage) as BergMadsen's (1987) material. The records of Tuarangia from New Zealand and Bornholm, Denmark are therefore all of Guzhangian age. Berg-Madsen (1987) also described a single internal mould from an erratic boulder in Poland as Tuarangia sp. (Fig. 9E), estimated as probably of early Late Cambrian (Furongian) age, although HinzSchallreuter (2000) commented that a late Middle Cambrian (Miaolingian) age was possible.

Tuarangia was considered to be a protobranchiate/ palaeotaxodont bivalve by Hinz-Schallreuter (2000) who considered Tuarangia gravgaerdensis and Tuarangia gravgaerdensis tenuiumbonata to be junior synonyms of Tuarangia paparua. Pseudomyona, placed within a new Order Pseudomyonida and new Family Pseudomyonidae by Hinz-Schallreuter (2000), was interpreted as a ribeirioid rostroconch. Vendrasco et al. (2011a) noted that Tuarangia and Pseudomyona shared similarities, such as a shell consisting of foliated calcite (MacKinnon 1982, Runnegar 1985, Vendrasco et al. 2010), which made the separation of Tuarangia and Pseudomyona proposed by HinzSchallreuter improbable. 
While Pseudomyona and Tuarangia are clearly distinct, their close relationship is strengthened by the present description of a series of interdigitating hinge teeth along the supra-apical surface of Pseudomyona groenlandica, in which respect it closely resembles Tuarangia (Fig. 9C). It is envisaged that the pair of dorsal flexible hinge zones on the sub-apical surface of Pseudomyona (Fig. 3B) subsequently coalesce and also acquire interdigitating teeth, likely developed from the halfpegmas, as the early growth stage is superseded by an amphidetic ligament (Fig. 9B, F). However, the teeth of Tuarangia are elongate (Fig. 9A, B) whereas those of Pseudomyona groenlandica are sub-circular (Fig. 8A). Hinz-Schallreuter (2000) pointed out differences in lateral profile, with the greatest height being near the subapical margin in Pseudomyona but at the supra-apical termination in Tuarangia but MacKinnon $(1982,1985)$ described great variation in the lateral profile, and many specimens are close to equilateral (Fig. 9D). The change in profile may reflect the migration of the umbonal region towards mid-length in Tuarangia, in connection with the development of the tooth-bearing sub-apical hinge.

In terms of age, specimens of Pseudomyona groenlandica are derived from an intermediate stratigraphic position between Pseudomyona queenslandica, which lacks the interdigitating tooth series on the supra-apical surface, and the true bivalved Tuarangia (Fig. 10). Pseudomyona and Tuarangia (Order Tuarangiida emend.) are considered to form a sister group to ribeirioids in which the incipient pegma (half-pegmas) was lost as the true bivalved shell of Tuarangia with taxodont dentition was developed (Fig. 10).

ORDOVICIAN

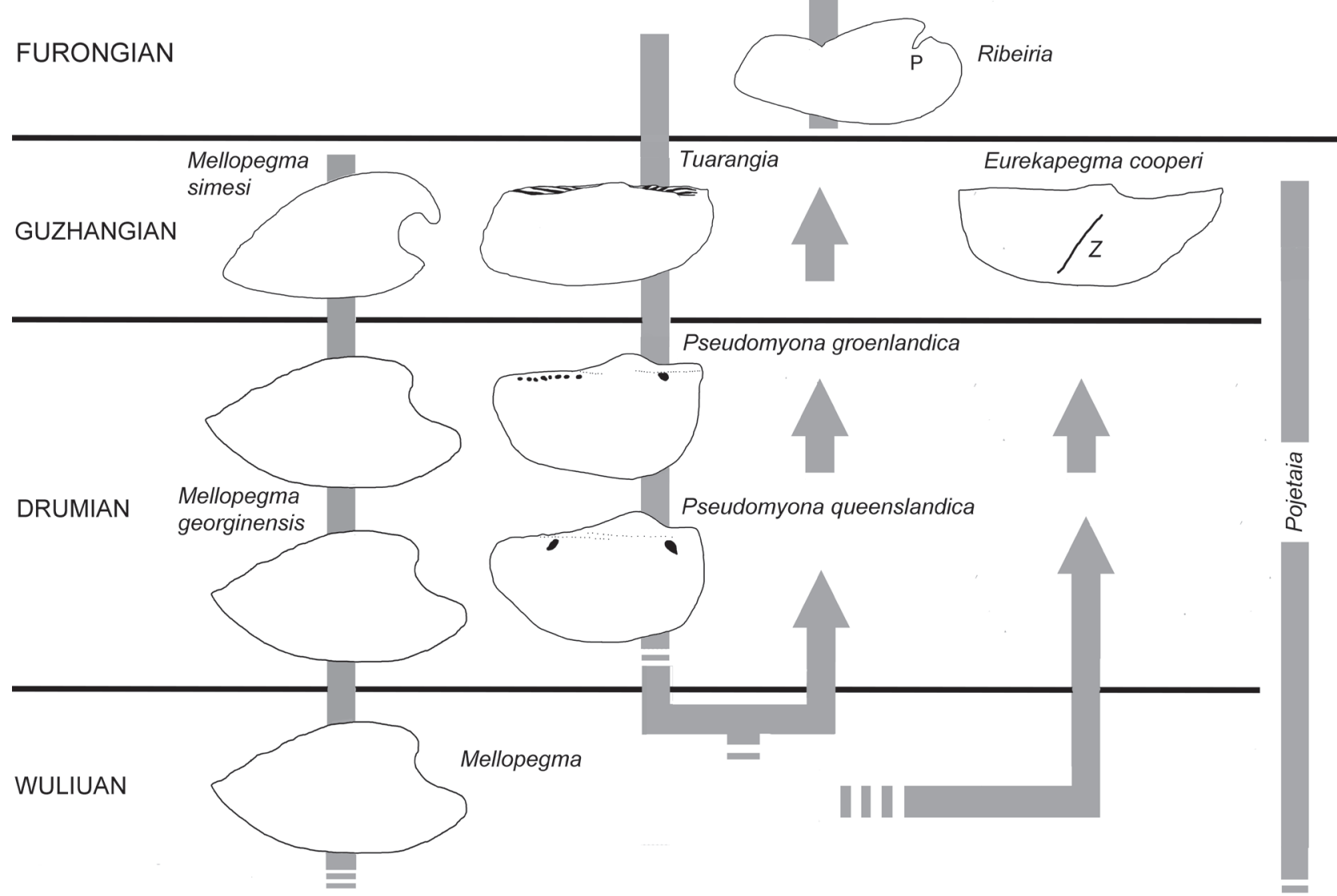

Figure 10. Stratigraphic relationships of Cambrian molluscs represented by their internal moulds. Abbreviations: $\mathrm{P}$ - pegma; $\mathrm{Z}$ - zygion. 


\section{Conclusions}

The Cambrian univalve Pseudomyona (Miaolingian, Series, Drumian Stage) is recorded for the first time from Laurentia, extending its previously known range from Australia and Siberia. Pseudomyona queenslandica (Runnegar \& Jell, 1976), the type species, occurs in the Ekspedition Bræ Formation of North Greenland and is followed in the overlying Fimbuldal Formation by Pseudomyona groenlandica sp. nov.

The proliferation of interdigitating hinge teeth on the supra-apical surface of Pseudomyona groenlandica supports an ancestral relationship with the slightly younger, bivalved, Tuarangia (Miaolongian Series, Guzhangian Stage; ?earliest Furongian Series).

Pseudomyona and Tuarangia are assigned to an emended Order Tuarangiida, referred to Class Rostroconchia as a sister group to ribeirioids. Pseudomyona may be the oldest rostroconch.

\section{Acknowledgements}

Samples were collected during the North Greenland Project (1978-1985) of Grønlands Geologiske Undersøgelse, now a part of the Geological Survey of Denmark and Greenland (GEUS), Copenhagen, Denmark. Vivianne Berg-Madsen, Jan Ove R. Ebbestad and Alexander Gubanov (Uppsala) are gratefully acknowledged for comments concerning the original manuscript, which was reviewed by John C.W. Cope (Cardiff) and Marika Polechová (Prague).

\section{References}

Axheimer, N., Eriksson, M.E., Ahlberg, P. \& Bengtsson, A. 2006. The middle Cambrian cosmopolitan key species Lejopyge laevigata and its biozone: new data from Sweden. Geological Magazine 143, 447-455.

DOI 10.1017/S0016756806002007

Barrande, J. 1881. Système Silurien de centre de la Bohême. Volume VI: Acéphales. Système Silurien de Centre de la Bohême. Volume VI: Acéphales. 342 pp. Privately published, Prague \& Paris.

Bengtson, S., Conway Morris, S., Cooper, B.J., Jell, P.A. \& RunNEGAR, B.N. 1990. Early Cambrian fossils from Australia. Memoir of the Australasian Association of Palaeontologists 9, 1-364.

Berg-Madsen, V. 1987. Tuarangia from Bornholm (Denmark) and similarities in Baltoscandian and Australasian late Middle Cambrian faunas. Alcheringa 11, 245-259. DOI 10.1080/03115518708618991

Bieler, R., Mikkelsen, P.M., Collins, E.A., Glover, V.L. et al. 2014. Investigating the Bivalve Tree of Life - An exemplar-based approach combining molecular and novel morphological characters. Invertebrate Systematics 28, 32-115. DOI $10.1071 /$ IS 13010
Bouchet, P., Rocroi, J.-P., Hausdorf, B., Kaim, A., Kano, Y., Nützel, A., Parkhaev, P., Schrödl, M. \& Strong, E.E. 2017. Revised classification, nomenclator and typification of gastropod and monoplacophoran families. Malacologia 61, 1-526. DOI 10.4002/040.061.0201

Carter, J.G. \& Aller, R.C. 1975. Calcification in the bivalve periostracum. Lethaia 8, 315-320.

DOI 10.1111/j.1502-3931.1975.tb00936.x

Carter, J.G., Campbell, D.C. \& Campbell, M.R. 2000. Cladistic perspectives on early bivalve evolution, 47-79. In HARPER, E.M., TAYlor, J.D. \& Crame, J.A. (eds) The Evolutionary Biology of the Bivalvia. Geological Society London, Special Publication 177. DOI 10.1144/GSL.SP.2000.177.01.04

Carter, J.G., CAmpbell, D.C. \& CAmpBell, M.R. 2006. Morphological phylogenetics of the early Bivalvia, 20-21. In Malchus, N. \& Pons, J.M. (eds) Abstracts and Posters of the "International Congress on Bivalvia" at the Universitat Autònoma de Barcelona, Spain, 22-27 July 2006. Organisms Diversity \& Evolution 6, Electronic supplement 16. [Illustrations available at $h t t p: / / w w w . s e n c k e n b e r g . u n i-f r a n k-$ furt.de/odes/06-16/Carter_et_al_Phylogeny-EarlyBiv.pdf] DOI 10.1016/j.ode.2006.09.001

Carter, J.G., Altaba, C.R., Anderson, L.C. Araujo, R. et al. 2011. A synoptical classification of the Bivalvia (Mollusca). University of Kansas Paleontological Institute, Paleontological Contributions 4, 1-46.

Checa, A.G., Salas, C., Harper, E.M. \& Bueno-Pérez, J. de Dios 2014. Early stage biomineralization in the periostracum of the 'living fossil' bivalve Neotrigonia. PlosOne 9(2), e9033. DOI 10.1371/journal.pone.0090033

Cope, J.C.W. 1997. The early phylogeny of the Class Bivalvia. Palaeontology 40, 713-746.

Cope, J.C.W. 2000. A new look at early bivalve phylogeny, 81-95. In TAYlor, E.M., TAYLOR, J.D. \& CRAme, J.A. (eds) The evolutionary biology of the Bivalvia. Geological Society London, Special Publication 177. DOI 10.1144/GSL.SP.2000.177.01.05

Cope, J.C.W. \& Kř́iž, J. 2013. The Lower Palaeozoic palaeobiogeography of Bivalvia, 221-241. In HARPER, D.A.T. \& SERvaIs, T. (eds) Early Palaeozoic biogeography and palaeogeography. Geological Society London, Memoir 38. DOI 10.1144/M38.16

Devaere, L., Clausen, S., Steiner, M., Javier, A.J. \& Vachard, D. 2013. Chronostratigraphic and palaeogeographic significance of an early Cambrian microfauna from the Heraultia Limestone, northern Montagne Noire, France, Palaeontologia Electronica 16(2), 16.2.17A. DOI $10.26879 / 366$

Elicki, O. \& Gürsu, S. 2009. First record of Pojetaia runnegari Jell, 1980 and Fordilla Barrande, 1881 from the Middle East (Taurus Mountains, Turkey) and critical review of Cambrian bivalves. Paläontolologische Zeitschrift 83, 267-291. DOI 10.1007/s12542-009-0021-9

Engeser, T. \& RiEDEL, F. 1996. The evolution of the Scaphopoda and its implications for the systematics of the Rostroconchia (Mollusca). Mitteilungen Geologisch-Paläontologisch Institut Universität Hamburg 79, 117-138. 
Etheridge, R. 1878. Notes on a few Silurian fossils from Ayrshire. Proceedings of the Royal Physical Society of Edinburgh 4, 167-176.

FAnG, Z. \& SÁnchez, T.M. 2012. Part N, revised, volume 1, chapter 16: Origin and early evolution Of the bivalvia. Treatise online 43,1-21. University of Kansas, Paleontological Institute. DOI 10.17161/to.v0i0.4275

Geyer, G. \& Peel, J.S. 2017, Middle Cambrian trilobites from the Ekspedition Bræ Formation of North Greenland, with a reappraisal of the genus Elrathina. Journal of Paleontology 91, 265-293, DOI 10.1017/jpa.2016.152

Geyer, G. \& Peel, J.S. 2020. Elrathia hensonensis nomen novum, new replacement name for Elrathia groenlandica Geyer and Peel, 2017 (Trilobita, Ptychopariacea). Journal of Paleontology 94, 1007. DOI 10.1017/jpa.2020.11

Geyer, G. \& Streng, M. 1998. Middle Cambrian pelecypods from the Anti-Atlas, Morocco. Revista Española de Paleontología, No. extr. Homenaje al Prof. Gonzalo Vidal, 83-96.

Giribet, G. 2008. Bivalvia, 105-141. In Ponder, W.F. \& Lindberg, D.R. (eds) Phylogeny and Evolution of the Mollusca. University of California Press, Berkeley \& Los Angeles. DOI 10.1525/california/9780520250925.003.0006

GonzÁlez, V.L., Andrade, S.C.S., Bieler, R., Collins, T.M., Dunn, C.W., Mikkelsen, P.M., Taylor, J.D. \& Giribet, G. 2015. A phylogenetic backbone for Bivalvia: an RNA-seq approach. Proceedings of the Royal Society of London, B 282, 20142332. DOI 10.1098/rspb.2014.2332

Grabau, A.W. 1900. Palaeontology of the Cambrian terranes of the Boston basin. Occasional Papers of the Boston Society of Natural History 4, 601-694.

Gubanov, A.P. \& Peel, J.S. 2003. The early Cambrian helcionelloid mollusc Anabarella Vostokova. Palaeontology 46, 1073-1087. DOI 10.1111/1475-4983.00334

Gubanov, A.P., Kouchinsky, A. \& Peel, J.S. 1999. The first evolutionary-adaptive lineage within fossil molluscs. Lethaia 32, 155-157. DOI 10.1111/j.1502-3931.1999.tb00534.x

Gubanov, A.P., Kouchinsky, A.V., Peel, J.S. \& Bengtson, S. 2004. Middle Cambrian molluscs of 'Australian' aspect from northern Siberia. Alcheringa 28, 1-20. DOI 10.1080/03115510408619272

Guo, J.-F., Li, G.-X., Qiang, Y.-Q., Song, Z.-C., Zhang, Z.-F., HAN, J. \& WANG, W.-Z. 2021. Watsonella crossbyi from the lower Cambrian (Terreneuvian, Stage 2) Yanjiahe Formation in Three Gorges area, South China. Palaeoworld 30(1), 1-19. DOI 10.1016/j.palwor.2020.04.006

HARPER, E.M. 1997. The molluscan periostracum: an important constraint in bivalve evolution. Palaeontology 40, 71-97.

Higgins, R.P. \& Thiel, H. 1988. Introduction to the study of meiofauna. 488 pp. Smithsonian Institution Press, Washington D.C.

Higgins, A.K., Ineson, J.R., Peel, J.S., Surlyk, F. \& Sønderholm, M. 1991a. Lower Palaeozoic Franklinian Basin of North Greenland. Grønlands Geologiske Undersøgelse Bulletin 160, 71-139.

Higgins. A.K., Ineson, J.R., Peel, J.S. Surlyk, F.S., \& SønderHoLm, M. 1991b. Cambrian to Silurian basin development and sedimentation, North Greenland, 109-161. In Tretrin, H.P. (ed.)
Geology of the Innuitian Orogen and Arctic Platform of Canada and Greenland. Geology of Canada 3. Geological Survey of Canada, Ottawa. DOI 10.1130/DNAG-GNA-E.109

Hinz-Schallreuter, I. 1995. Muscheln (Pelecypoda) aus dem Mittelkambrium von Bornholm. Geschiebekunde aktuell 11(3), 71-84.

Hinz-Schallreuter, I. 2000. Middle Cambrian Bivalvia from Bornholm and a review of Cambrian bivalved Mollusca. Revista Españlola de Micropaleontología 32, 225-242.

Horný, R.J. 1965. Cyrtolites ConRad, 1838 and its position among the Monoplacophora (Mollusca). Sborník Národního muzea, Řada B, Přirodní védy 21, 57-70.

InESON, J.R. \& PeEL, J.S. 1997. Cambrian shelf stratigraphy of North Greenland. Geology of Greenland Survey Bulletin 173, 1-120. DOI 10.34194/ggub.v173.5024

Ineson, J.R. \& Peel, J.S 2011. Geological and depositional setting of the Sirius Passet Lagerstätte (Early Cambrian), North Greenland. Canadian Journal of Earth Sciences 48, 1259-1281. DOI 10.1139/e11-018

Ineson, J.R., Surlyk, F., Higgins, A.K. \& Peel, J.S. 1994. Slope apron and deep shelf sediments of the Brønlund Fjord and Tavsens Iskappe Groups (Lower Cambrian-Lower Ordovician), North Greenland: stratigraphy, facies and depositional setting. Geology of Greenland Survey Bulletin 169, $7-24$.

Jell, P.A. 1980. Earliest known bivalve on Earth - a new Early Cambrian genus from South Australia. Alcheringa 4, 233-239. DOI 10.1080/03115518008618934

KNIGHT, J.B. 1952. Primitive fossil gastropods and their bearing on gastropod classification. Smithsonian Miscellaneous Collections 117(13), 1-56.

Kobayashi, T. 1933. Faunal study of the Wanwanian (basal Ordovician) series with special notes on the Ribeiridae and the Ellesmereoceroids. Journal of the Faculty of Science Imperial University of Tokyo Section II Geology, Mineralogy, Geography, Seismology 3, 249-328.

Koneva, S.P. 1976. New members of the Class Stenothecoida from the Lower Cambrian of central Kazakhstan. Paleontological Journal 1976(2), 230-233.

KonEva, S.P. 1979. Stenothecoids and inarticulate brachiopods of the Lower Cambrian and basal Middle Cambrian of central Kazakhstan. 123 pp. Nauka, Alma-Ata. [in Russian]

Kouchinsky, A.V. 1999. Shell microstructures of the Early Cambrian Anabarella and Watsonella as new evidence on the origin of the Rostroconchia. Lethaia 32, 173-180. DOI 10.1111/j.1502-3931.1999.tb00537.x

Kouchinsky, A., Bengtson, S., Clausen, S., Gubanov, A., MalinKy, J.M. \& Peel, J.S. 2011. A middle Cambrian fauna of skeletal fossils from the Kuonamka Formation, northern Siberia. Alcheringa 35, 123-189.

DOI 10.1080/03115518.2010.496529

Kouchinsky, A., Bengtson, S., Landing, E., Steiner, M., VendraSCO, M. \& Ziegler, K. 2017. Terreneuvian stratigraphy and faunas from the Anabar uplift, Siberia. Acta Palaeontologica Polonica 62, 311-340. DOI 10.4202/app.00289.2016

Lemer, S., Bieler, R. \& Giribet, G. 2019. Resolving the relationships of clams and cockles: dense transcriptome sampling 
drastically improves the bivalve tree of life. Proceedings of the Royal Society of London, B 286, 20182684.

DOI 10.1098/rspb.2018.2684

Li, G., Zhao, X., Gubanov, A., Zhu, M. \& NA, L. 2011. Early Cambrian Mollusc Watsonella crosbyi: a potential GSSP index fossil for the base of the Cambrian Stage 2. Acta Geologica Sinica, English Edition 85, 309-319.

DOI 10.1111/j.1755-6724.2011.00400.x

Linnaeus, C. 1758. Systema naturce per regna tria naturce, secundum classes, ordines, genera, species, cum characteribus, differentiis, synonymis, locis. Vol. 1 (10 th edition). 824 pp. Laurentius Salvius, Stockholm. DOI 10.5962/bhl.title.542

MacKinnon, D.I. 1982. Tuarangia paparua, n. gen. and n. sp., a late Middle Cambrian pelecypod from New Zealand. Journal of Paleontology 56, 589-598.

MacKinnon, D.I. 1985. New Zealand late Middle Cambrian molluses and the origin of Rostroconchia and Bivalvia. Alcheringa 9, 65-81. DOI 10.1080/03115518508618959

Mazaev, A.V. 2012. Anetshelloida, a new rostroconch order (Mollusca: Rostroconchia). Paleontological Journal 46, 121-131. DOI 10.1134/S0031030112020074

Neumayr, M. 1891. Beiträge zu einer morphologischen Eintheilung der Bivalven. Denkschriften der Mathematisch Naturwissenschaftlichen Classe der Kaiserlichen Akademie der Wissenschaften 58, 708-801.

Nevesskaja, L.A. 2009. Principles of systematics and the system of bivalves. Paleontological Journal 43, 1-11 [Paleontologicheskii Zhurnal 2009, 1, 3-13]. DOI 10.1134/S0031030109010018

Parkhaev, P.Yu. 2001. Molluscs and siphonoconchs, 133-210. In Alexander, E.M., Jago, J.B., Rozanov, A.Yu. \& Zhuravlev, A.Yu. (eds) The Cambrian biostratigraphy of the Sainsbury Basin, South Australia. Transactions of the Palaeontological Institute 282. Russian Academy of Sciences.

Parkhaev, P.Yu. 2002. Phylogenesis and the system of the Cambrian univalved mollusks. Paleontological Journal 36, 25-36. [Paleontologicheskii Zhurnal 2002(1), 27-39].

Parkhaev, P.Yu. 2008. The early Cambrian radiation of Mollusca, 33-69. In Ponder, W.F. \& Lindberg, D.R. (eds) Phylogeny and evolution of the Mollusca. University of California Press, Berkeley. DOI 10.1525/california/9780520250925.003.0003

Parkhaev, P.Yu. 2017. Origin and the Early Evolution of the Phylum Mollusca. Paleontological Journal 51, 663-686. [Paleontologicheskii Zhurnal 2017(6), 91-112]. DOI 10.1134/S003103011706003X

ParkhaEv, P.Yu. 2019. Cambrian molluscs of Australia: overview of taxonomy, biostratigraphy and paleobiogeography. Stratigraphy and Geological Correlation 27, 181-206. DOI 10.1134/S0869593819020072

Peel, J.S. 1988. Molluscs of the Holm Dal Formation (late Middle Cambrian), central North Greenland. Meddelelser om Grønland, Geoscience 20, 145-168.

PeEL, J.S. 1989. A Lower Cambrian Eotebenna (Mollusca) from Arctic North America. Canadian Journal of Earth Sciences 26, 1501-1503. DOI 10.1139/e89-127

Peel, J.S. 1991a. The Classes Tergomya and Helcionelloidea, and early molluscan evolution. Bulletin Grønlands Geologiske Undersøgelse 161, 11-65.

Peel, J.S. 1991b. Functional morphology of the Class Helcionelloida nov., and the early evolution of the Mollusca, 157-177. In Simonetta, A. \& Conway Morris, S. (eds) The early evolution of Metazoa and the significance of problematic taxa. Cambridge University Press, Cambridge.

Peel, J.S. 1994. An enigmatic cap-shaped fossil from the Middle Cambrian of North Greenland. Bulletin Grønlands Geologiske Undersøgelse 169, 149-155.

Peel, J.S. 2004. Pinnocaris and the origin of scaphopods. Acta Palaeontologica Polonica 49, 543-550.

Peel, J.S. 2006. Scaphopodization in Palaeozoic molluscs. Palaeontology 49, 1357-1364. DOI 10.1111/j.1475-4983.2006.00599.x

Plazzi, F., Ceregato, A., Taviani, M. \& Passamonti, M. 2011. A molecular phylogeny of bivalve mollusks: ancient radiations and divergences as revealed by mitochondrial genes. PLoS ONE 6(11), e27147. DOI 10.1371/journal.pone.0027147

PoJeTA, J., JR 1975. Fordilla troyensis Barrande and early pelecypod phylogeny. Bulletins of American Paleontology 67, 363-384.

PojetA, J., JR 2000. Cambrian Pelecypoda (Mollusca). American Malacological Bulletin 15, 157-166.

Pojeta, J., JR \& Runnegar, B. 1976. The paleontology of rostroconch mollusks and the early history of the phylum Mollusca. United States Geological Survey Professional Paper 968, 1-88. DOI 10.3133/pp968

Pojeta, J., Jr, Runnegar, B., Morris, N.J. \& Newell, N.D. 1972. Rostroconchia: a new class of bivalved mollusks. Science, New Series 177, 264-267. DOI 10.1126/science.177.4045.264

Ponder, W.F., Lindberg, D.R. \& Ponder, J.M. 2020. Biology and evolution of the Mollusca, Volume 2. 870 pp. CRC Press, Boca Raton, Florida. DOI 10.1201/9781351115254

Robison, R.A. 1984. Cambrian Agnostida of North America and Greenland Part I, Ptychagnostidae. University of Kansas, Paleontological Contributions, Paper 109, 1-59.

RunNEGAR, B. 1978. Origin and evolution of Class Rostroconchia. Philosophical Transactions of the Royal Society of London, B 264, 319-333. DOI 10.1098/rstb.1978.0070

RunNegar, B. 1983. Molluscan phylogeny revisited. Memoir of the Association of Australasian Palaeontologists 1, 121-144.

RunNEgAR, B. 1985. Shell microstructures of Cambrian molluscs replicated by phosphate. Alcheringa 9, 245-257. DOI 10.1080/03115518508618971

RunNEGAR, B. 1996. Early evolution of the Mollusca: the fossil record, 77-87. In TAYLOR, J. (ed.) Origin and Evolutionary Radiation of the Mollusca. Oxford University Press.

Runnegar, B. \& Bentley, C. 1983. Anatomy, ecology and affinities of the Australian Early Cambrian bivalve Pojetaia runnegari Jell. Journal of Paleontology 57, 73-92.

Runnegar, B. \& Jell, P.A. 1976. Australian Middle Cambrian molluscs and their bearing on early molluscan evolution. Alcheringa 1, 109-138. DOI 10.1080/03115517608619064

Runnegar, B. \& Pojeta, J., JR 1980. The monoplacophoran mollusk Yochelcionella identified from the Lower Cambrian of Pennsylvania. Journal of Paleontology 54, 635-636. 
Runnegar, B. \& Pojeta, J., JR 1992. The earliest bivalves and their Ordovician descendants. American Malacological Bulletin 9, 117-122.

Schneider, J.A. 2001. Bivalve systematics during the 20th century. Journal of Paleontology 75, 1119-1127. DOI 10.1666/0022-3360(2001)075<1119:BSDTC $>2.0 . C O ; 2$

Sharma, P.P., González, V.L., Kawauchi, G.Y., Andrade, S.C., Guzmán, A., Collins, T.M., Glover, E.A., Harper, E.M., Healy, J.M., Mikkelsen, P.M., Taylor, J.D., Bieler, R. \& Giribet, G. 2012. Phylogenetic analysis of four nuclear protein-encoding genes largely corroborates the traditional classification of Bivalvia (Mollusca). Molecular Phylogenetics and Evolution 65, 64-74. DOI 10.1016/j.ympev.2012.05.025

Sharma, P.P., Zardus, J.D., Boyle, E.E., GonzÁlez, V.L., Jennings, R.M., McIntyre, E., Wheeler, W.C., Etter, R.J. \& GiRIBET, G. 2013. Into the deep: a phylogenetic approach to the bivalve subclass Protobranchia. Molecular Phylogenetics and Evolution 69, 188-204.

DOI 10.1016/j.ympev.2013.05.018

Vendrasco, M. 2012. Early evolution of molluscs, 1-43. In Fyodorov, A. \& YAKovlev, H. (eds) Mollusks: morphology, behaviour and ecology. Nova Science, New York.

Vendrasco, M.J., Porter, S.M., Kouchinsky, A., LI, G. \& FernandeZ, C.Z. 2010. New data on molluscs and their shell microstructures from the Middle Cambrian Gowers Formation, Australia. Palaeontology 53, 97-135. DOI 10.1111/j.1475-4983.2009.00922.x
Vendrasco, M.J., Checa, A.G. \& Kouchinsky, A.V. 2011a. Shell microstructure of the early clam Pojetaia and the independent origin of nacre within the Mollusca. Palaeontology 54, 825-850. DOI 10.1111/j.1475-4983.2011.01056.x

Vendrasco, M.J., Kouchinsky, A.V., Porter, S.M. \& Fernandez, C.Z. 2011b. Phylogeny and escalation in Mellopegma and other Cambrian molluscs. Palaeontologia Electronica 14, $1-44$.

Vermeis, G.J. 1987. Evolution and escalation. An ecological history of life. 527 pp. Princeton University Press, Princeton. DOI 10.1515/9780691224244

Vostokova, V.A. 1962. Cambrian gastropods from Siberian platform and Taimyr. Statei po Paleontologii I Biostratigrafii 28, 51-74. [in Russian]

Wagner, P.J. 1997. Patterns of morphologic diversification among the Rostroconchia. Paleobiology 23, 115-150. DOI 10.1017/S0094837300016675

WALLER, T.R. 1998. Origin of the molluscan Class Bivalvia and a phylogeny of major groups, 1-45. In Johnston, P.A. \& Haggart, J.W. (eds) Bivalves: An eon of evolution: Paleobiological studies honouring Norman D. Newell. University of Calgary Press, Calgary.

Yochelson, E.L. 1969. Stenothecoida, a proposed new class of Cambrian Mollusca. Lethaia 2, 49-62.

DOI 10.1111/j.1502-3931.1969.tb01250.x

Yochelson, E.L. 1981. Fordilla troyensis Barrande: "the oldest known pelecypod" may not be a pelecypod. Journal of Paleontology 55, 113-125. 